\begin{tabular}{|c|c|c|}
\hline & $\begin{array}{c}\text { GEOAMBIENTE ON-LINE } \\
\text { Revista Eletrônica do Curso de Geografia - UFG/REJ } \\
\text { Graduação e Pós-Graduação em Geografia } \\
\text { htpp://www.revistas.ufg.br/geoambiente } \\
\text { Jataí-Go | n } 31 \text { | Maio-Agosto/2018 }\end{array}$ & $\begin{array}{c}\text { :GEO } \\
\text { G }\end{array}$ \\
\hline
\end{tabular}

\title{
ZONEAMENTO AMBIENTAL DA BACIA HIDROGRÁFICA DO CÓRREGO ACÔGO (MS)
}

\author{
Lidiane Perbelin Rodrigues ${ }^{1}$, Emerson Figueiredo Leite ${ }^{2}$
}

(1 - Universidade Federal do Mato Grosso do Sul, Campus Aquidauana, Mestranda em Geografia, lidiane_perbelin@hotmail.com, 2 - Universidade Federal do Mato Grosso do Sul, Docente, emerson.leite@ufms.br)

Resumo - Planejar as ações antrópicas sobre o meio ambiente ganha importância devido à necessidade de compatibilizar a proteção ambiental com o desenvolvimento socioeconômico. Nesse contexto, o Zoneamento Ambiental é uma etapa fundamental do Planejamento Ambiental.O presente trabalho objetiva propor um Zoneamento Ambiental para a bacia hidrográfica do córrego Acôgo-MS, localizada nos municípios de Anastácio e Aquidauana-MS. A elaboração deste Zoneamento pautou-se na adoção de etapas sistemáticas guiadas pela metodologia proposta por Crepani et al. (2001) com adequações metodológicas. Para a elaboração dos produtos cartográficos apresentados neste trabalho utilizou-se o software de SIG Sistema de Processamento de Informações Georreferenciadas (SPRING) em sua versão 5.2.7, em especial a Linguagem Espacial para Geoprocessamento Algébrico (LEGAL), que possibilitou a elaboração dos mapas de síntese apresentados. Como resultado desta pesquisa obteve-se um Zoneamento Ambiental da bacia hidrográfica do córrego Acôgo-MS com quatro zonas de manejos diferenciados, a qual foi realizada prospecções a fim de subsidiar o planejamento ambiental e contribuir com o desenvolvimento sustentável da área de estudo.

Palavras-chave: Bacia Hidrográfica. Geoprocessamento. Zoneamento Ambiental.

\section{ENVIRONMENTAL ZONING OF THE HYDROGRAPHIC BASIN OF THE ACÔGO STREAM - MATO GROSSO DO SUL STATE (MS)}

Abstract - Planning anthropic actions over the environment becomes important due to the need of align environmental protection with socioeconomic development. In this context, Environmental Zoning is a key step of Environmental Planning. This work main to propose an Environmental 


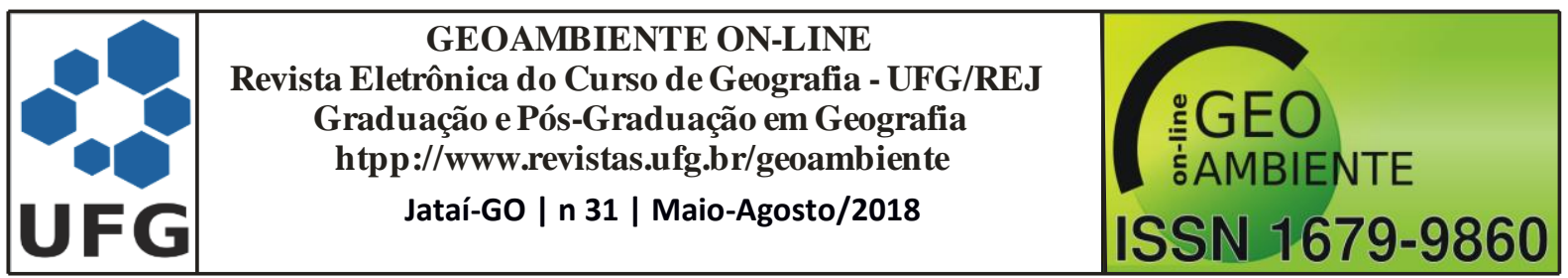

Zoning to the hydrographic basin of the Acôgo stream - Mato Grosso do Sul State (MS). The hydrographic basin is located in the municipalities of Anastácio and Aquidauana (MS). The development of this Zoning was based on systemic stages guided by the methodology proposed by Crepani et al.(2001) with some methodological adaptations. In order to produce the cartographic products presented in this work it was used the GIS software Georeferenced Information Processing System (SPRING) in its version 5.2.7, especially the LEGAL programming language enabled the production of the presented synthesis maps. As a result of this research it was obtained an Environmental Zoning of the hydrographic basin of the Acôgo stream - MS, it was generated four different management zones on which was realized prospection in order to subsidize the environmental planning and contribute with the sustainable development of the studying area.

Key words: Hydrographic Basin. Geoprocessing. Environmental Zoning.

\section{ZONIFICACIÓN AMBIENTAL LA CUENCA HIDROGRÁFICA DEL ARROYO ACÔGO -ESTADO DE MATO GROSSO DO SUL (MS)}

Resumen - Planear las acciones antrópicas sobre el medio ambiente gana importancia debido a la necesidad de compatibilizar la protección ambiental con el desarrollo socioeconómico. En este contexto, la Zonificación Ambiental es una etapa fundamental de la Planificación Ambiental. El presente trabajo objetiva proponer una Zonificación Ambiental para la cuenca hidrográfica del Arroyo Acôgo-MS. Esta cuenca hidrográfica se encuentra ubicada en los municipios de Anastácio y Aquidauana-MS. La elaboración de esta Zonificación se basó en la adopción de etapas sistemáticas guiadas por la metodología propuesta por Crepani et al. (2001) con adecuaciones metodológicas. Para la elaboración de los productos cartográficos presentados en este trabajo se utilizó el software de SIG Sistema de Procesamiento de Informaciones Georreferenciadas (SPRING) en su versión 5.2.7. en especial el Lenguaje Espacial para Geoprocesamiento Algebraico (LEGAL) posibilitó la elaboración de mapas de síntesis presentados. Como resultado de esta investigación se obtuvo una Zonificación Ambiental de la cuenca hidrográfica del arroyo Acôgo-MS con cuatro zonas de manejos diferenciados, la cual fue realizada prospecciones a fin de subsidiar la planificación ambiental y contribuir con el desarrollo sostenible del área de estudio.

Palabras clave: Cuenca Hidrográfica. Geoprocesamiento. Zonificación Ambiental.

\section{INTRODUÇÃO}




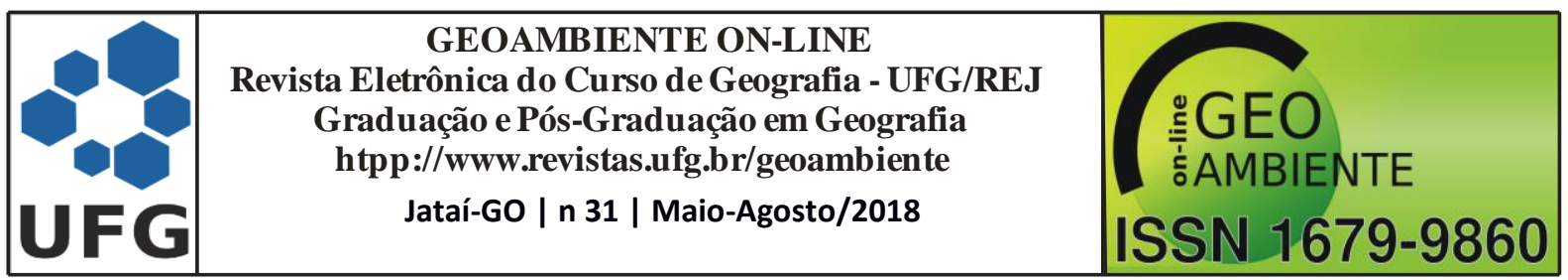

As intervenções antrópicas sobre o meio ambiente repercutem sobre o equilíbrio dos geossistemas levando à perda da qualidade ambiental indispensável para a sobrevivência do homem como ser biológico, geram perdas econômicas e sociais. Nessa perspectiva, planejar essas intervenções torna-se fundamental para compatibilizar o desenvolvimento econômico com a proteção dos recursos naturais e o equilíbrio dos geossistemas.

Dessa forma, a crescente preocupação com danos oriundos desses desequilíbrios torna-se compreensível, tendo em vista que no Brasil, a ocupação do território pautou-se, historicamente, na exploração predatória dos recursos naturais, num processo de degradação ambiental que afetou especialmente os recursos hídricos e o solo (RIBEIRO et al., 2005).

O Cerrado, por exemplo, a partir da década de 1950 - período de expansão da fronteira agrícola - passou por um massivo processo de destruição de sua fauna e flora nativa, perdendo cerca de $60 \%$ de sua área original (HENRIQUES, 2003). Nesse período, a falta de conhecimento científica sobre o ecossistema do Cerrado contribuiu para a ocupação desordenada, que culminou com um intenso processo de desmatamento nessas regiões (LANZA et al., 2014) alterando o meio ambiente em ritmo acelerado, gerando desequilíbrio nos ecossistemas, especialmente devido ao manejo inadequado do solo e dos recursos hídricos (SÃO MIGUEL et al., 2017).

Os recursos hídricos do cerrado possuem importância muito além de suas dimensões espaciais configurando-se um sua importância estratégica para o país, uma vez que nele encontram-se as nascentes dos principais rios brasileiros: Paraná, São Francisco, da margem direita do Amazonas, Tocantins. Suas águas são imprescindíveis para a geração de energia elétrica, irrigação, abastecimento de cidades, indústria, recreação e turismo (LIMA, 2009; SAWYER, 2009).

Diante do exposto, planejar as intervenções antrópicas nas regiões de domínio do Cerrado Brasileiro torna-se capital, devido a sua importância ambiental e seu atual estado de vulnerabilidade. Entretanto, planejar essas ações é um ato complexo que envolve uma série de informações sobre o meio a qual se pretende interferir e a adoção de metodologias adequadas. Atualmente entende-se que o Zoneamento Ambiental seja a base para esse planejamento.

No intuito de aplicar a técnica de zoneamento e corroborar com os estudos sobre o bioma Cerrado, o presente artigo buscou como célula de análise a bacia hidrográfica do córrego AcôgoMS, que localiza-se à porção centro-oeste do estado de Mato Grosso do Sul - região de transição entre a Planície Pantaneira e o Planalto de Maracajú, inserida na Bacia Hidrográfica do Alto 


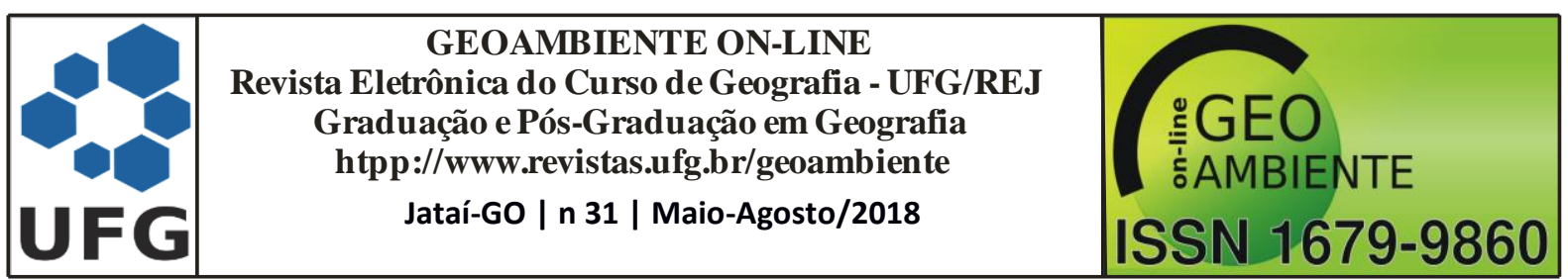

Paraguai - e abrange partes territoriais dos municípios de Anastácio e Aquidauana, compreendida

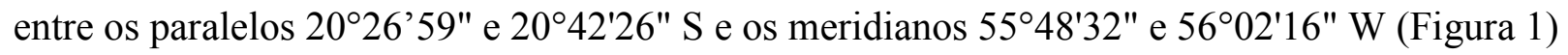

Situada à $120 \mathrm{~km}$ de distância da capital Campo Grande, acesso pela BR 262, a bacia possuí área de 362.7 km², abrangendo partes territoriais dos municípios de Anastácio $\left(360.2 \mathrm{~km}^{2}\right)$ e Aquidauana $\left(2.5 \mathrm{~km}^{2}\right)$ e recebe o nome de seu principal canal fluvial, o córrego Acôgo, que nasce nas proximidades do km 12 da Rodovia MS 345 (Sentido Anastácio-Bonito), e percorre $34.27 \mathrm{~km}$ até a sua foz, à margem esquerda do rio Aquidauana.

Figura 1: Localização da bacia hidrográfica do córrego Acôgo-MS

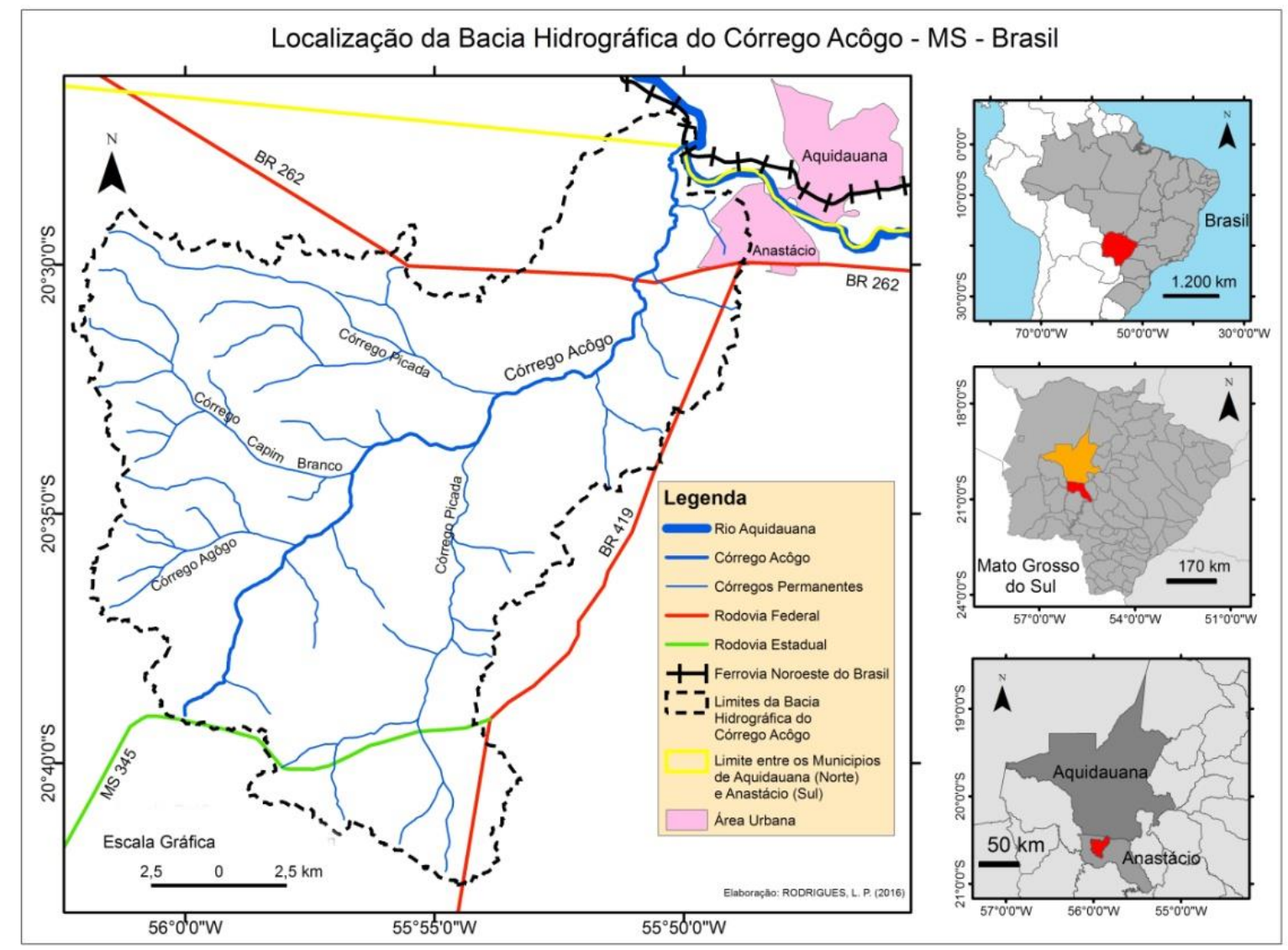

Organização: Rodrigues, L.P (2018).

No baixo curso do córrego Acôgo, à sua margem direita, encontra-se a cidade de Anastácio, sede do município de mesmo nome, o qual possui segundo o Censo de 2010, população de 23.835 habitantes, e no extremo noroeste a bacia abrange um trecho do município de Aquidauana, que conta com população de 45.615 habitantes. Com base nos dados apresentados e na análise dos dados censitários de 2010, analisados por setor estima-se que haja cerca de 4,989 


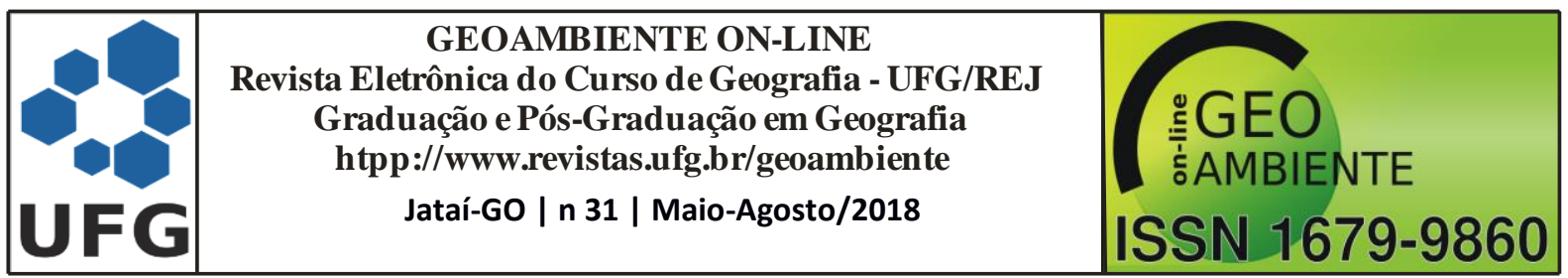

habitantes na bacia, o que corresponde a uma densidade demográfica de $13,74 \mathrm{hab} / \mathrm{km}^{2}$ (IBGE, 2015),

\section{REFERENCIAL TEÓRICO}

As ações que alteram negativamente os processos ambientais podem ser entendidas como degradação, ou seja "alteração adversa dos processos, funções ou componentes ambientais" (SANCHEZ, 2013, p. 27), e podem ocorrer em qualquer tipo de ambiente, ademais, Lage e Peixoto (2008), apontam que os diversos ambientes apresentam diferentes graus de vulnerabilidade frente aos processos degradantes que podem levar a perda de biodiversidade assoreamento dos rios, empobrecimento do solo, e perda da qualidade da água, etc., sendo a ação antrópica o fator agravante nesse processo.

Dessa forma, torna-se necessário o planejamento das ações antrópicas visando uma utilização e ocupação ordenada do território, que provoquem modificações positivas nos fluxos de matéria e energia, promovendo a sustentabilidade e equilíbrio dos geossistemas e promovam o desenvolvimento sustentável. Essas medidas tomadas a partir de análises detalhadas das características socioeconômicas, potencialidades e fragilidades do território correspondem ao Planejamento Ambiental (TEIXEIRA et al., 2017), oferecem alternativas racionais para organizar o uso da terra, compatibilizando o uso dos recursos naturais com a proteção de ambientes ameaçados e a melhora na qualidade de vida das populações (SANTOS, 2004).

Ao analisarmos o Planejamento Ambiental sob a perspectiva geossistêmica, entende-se a necessidade de realizar-se o planejamento integrado dos meios físico, biótico e antrópico uma vez que a paisagem observada no presente é resultado de processos socioambientais do passado, e será diferente no futuro, e está evolução depende das ações do presente, ou seja, dos padrões de organização do espaço adotados e sua evolução ao longo do tempo (BARROSO et al., 2015; FERREIRA et al. 2016).

Para Silva e Rodrigues (2014), o Planejamento Ambiental exige uma série de ferramentas, posturas e políticas voltadas a organização do espaço geográfico instrumentalize a gestão ambiental do âmbito governamental e da sociedade civil.

No Brasil, a Política Nacional de Meio Ambiente (PNMA), é o principal marco para a política ambiental e inova ao privilegiar abordagens estratégicas para a relação entre a produção e o meio ambiente, que influenciam a participação da sociedade civil e articulação gestores de 


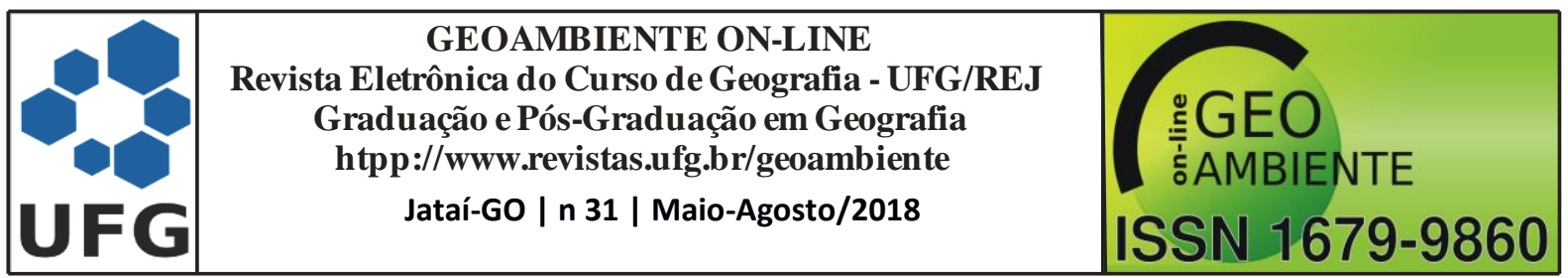

diversas instituições públicas nas decisões atinentes a temática ambiental, além de prever a utilização de instrumentos de gestão, tais como: o estabelecimento de padrões de qualidade, o zoneamento, a avaliação de impactos e o licenciamento ambiental (FERREIRA; SALLES, 2016; GASS; VERDUM, 2016),

Para a elaboração do Planejamento Ambiental, as bacias hidrográficas são consideradas a melhor unidade de análise espacial, sendo reconhecida pela Política Nacional de Recursos Hídricos (PNRH) como unidade de Planejamento e Gestão. Dessa forma, Carvalho (2014) aponta que ao utilizar a bacia hidrográfica como unidade de análise é possível aplicar um modelo Planejamento Ambiental Integrado de modo a compreender as inter-relações entre os meios físico, biótico e antrópico dadas num determinado território, com caráter indicativo e normativo para o uso e ocupação do solo, e deve ser implementado através do Zoneamento Ambiental.

Para Guedes et al. (2016), o Zoneamento Ambiental é a base do Planejamento Ambiental. Auxilia no ordenamento físico e territorial, formulação e implantação de políticas e estratégias para o desenvolvimento a partir da definição zonas homogêneas em função de variáveis socioambientais. Silva e Santos (2011) apontam que essa regionalização ocorre mediante a determinados critérios pré-estabelecidos, que resultam de análises dinâmicas e regionalização de atributos relevantes, visando a análise integrada.

Segundo Seiffert (2011), o Zoneamento Ambiental tem por objetivo definir a aptidão de ocupação de uma determinada área, podendo-se criar zonas homogêneas com maiores ou menores graus de restrição para as inserções antrópicas e pode ser realizado em qualquer área que apresente interesse para o planejador, sua extensão pode ter limites políticos como países ou limites naturais como uma bacia hidrográfica.

Na elaboração do zoneamento, são necessário um conjunto de informações atinentes a área a ser analisada que devem ser espacializadas para a indicação de áreas homogêneas para o planejador. Nesse processo, a utilização de técnicas de Geoprocessamento é indispensável, assim como a adoção de metodologias consistentes que levem ao planejamento da conservação, recuperação, métodos mitigadores, educação ambiental (BACANI; LUCHIARI,2014; GUEDES et al., 2016)

\section{MATERIAIS E MÉTODOS}




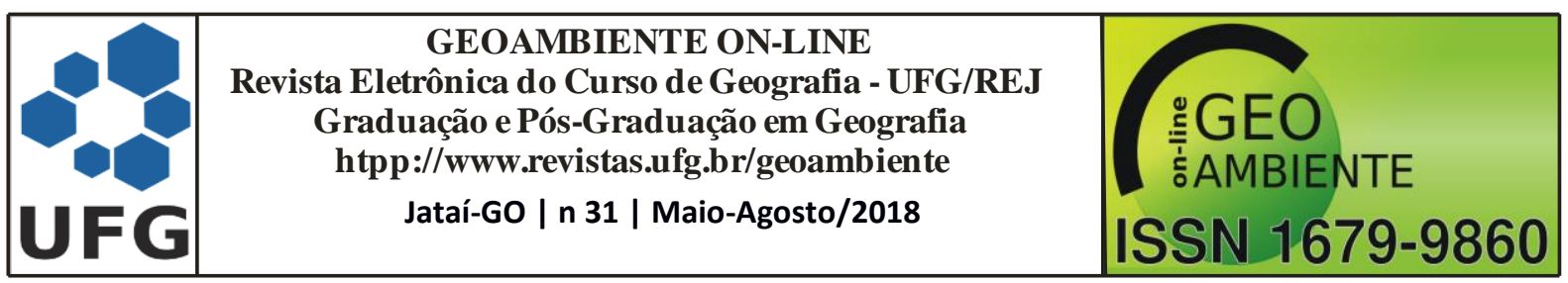

Para a proposição do Zoneamento Ambiental da bacia hidrográfica do córrego Acôgo adaptou-se a metodologia de Crepani et al. (2001) - que busca analisar de forma integrada os elementos que compõem a gênese da paisagem (Figura 2). Neste trabalho usou-se software de SIG denominado Sistema de Processamento de Informações Georreferenciadas (SPRING 5.2.7), do qual destaca-se a utilização da Linguagem Espacial para Geoprocessamento Algébrico (LEGAL), um editor e executor de uma linguagem de álgebra de mapas, na qual o usuário pode programar e executar um modelo espacial matemático relacionado com o sua área de estudo, para realizar procedimentos como ponderação, fatiamento e operações booleanas (FELGUEIRAS, 2006).

Figura 2: Metodologia para o Zoneamento Ambiental da Bacia Hidrográfica do Córrego Acôgo-MS

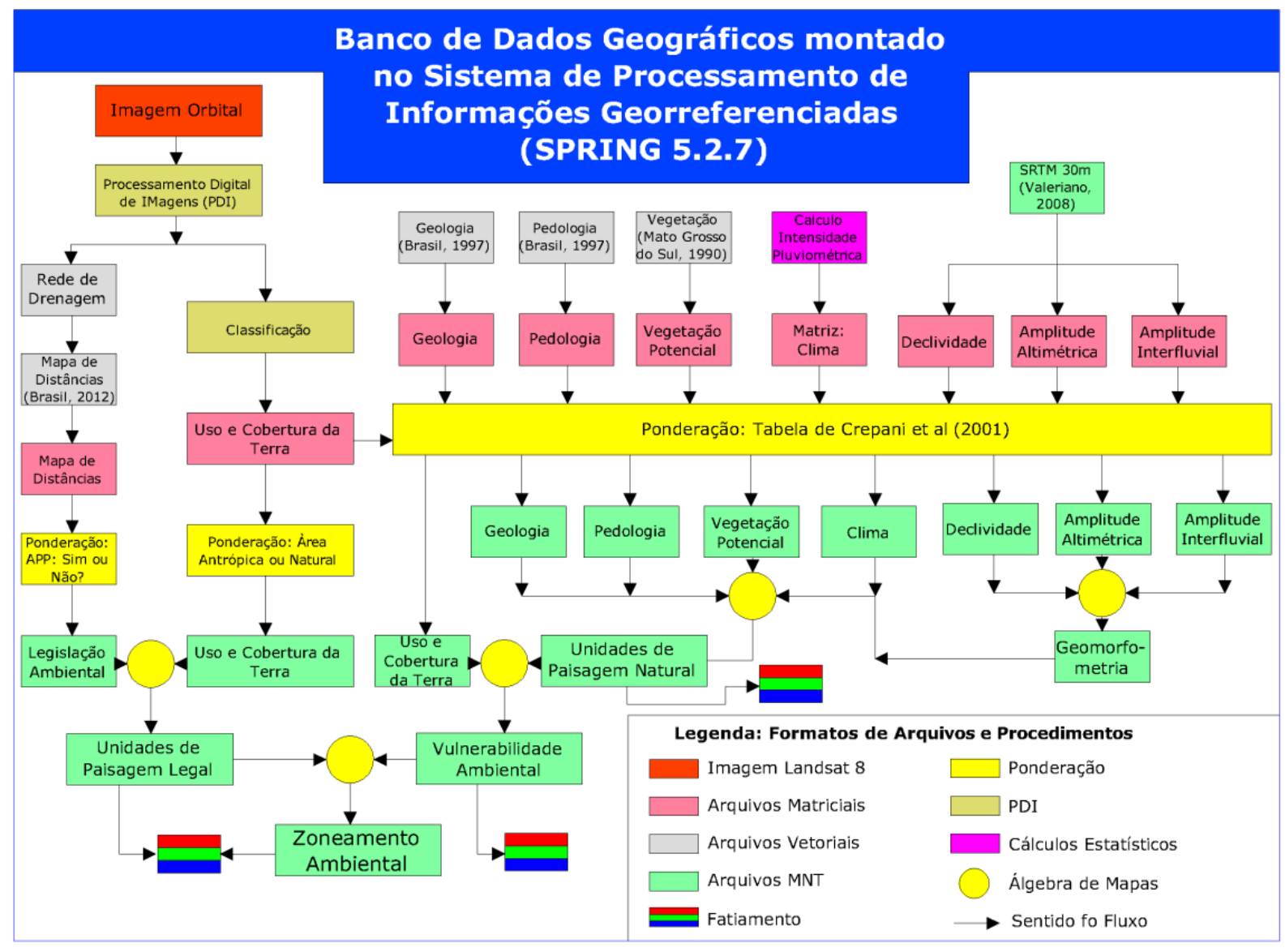

Organização: Rodrigues, L.P (2018).

O Zoneamento elaborado em escala 1:100.000, caracteriza a Bacia do Córrego Acôgo quanto a vulnerabilidade ou estabilidade frente aos processos erosivos e sua atual situação legal, de cumprimento ou não do Código Florestal Brasileiro (BRASIL, 2012). Dessa forma, dividiu-se 


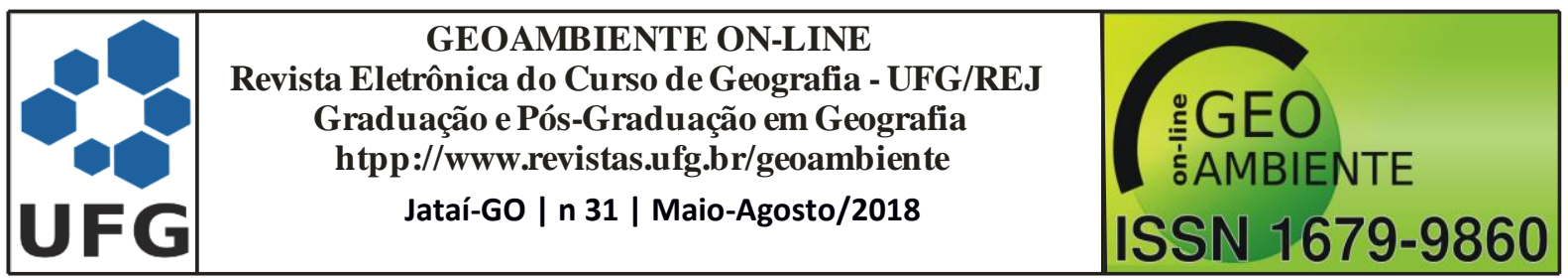

esta metodologia em 4 partes: Unidades de Paisagem Natural (UPN), Vulnerabilidade Ambiental, Unidades de Paisagem Legal (UPL) e Zoneamento Ambiental.

Unidades de Paisagem Natural (UPN) - Representa a capacidade natural da área de estudo resistir ou favorecer aos processos erosivos (Crepani et al. 2001), sendo obtido através da síntese entre os mapas de Geologia, Geomorfometria (síntese entre os mapas de Declividade, Amplitude Altimétrica e Amplitude Interfluvial), Pedologia, Clima (Intensidade Pluviométrica) e Vegetação Potencial (correspondente à Vegetação Original da área de Estudo).

Primeiramente foram elaborados e/ou compilados mapas de Geologia, Geomorfometria, Pedologia, Clima e Vegetação Potencial para a área de estudo, posteriormente cada uma das classes apresentadas nos mapas de foram analisadas conforme sua capacidade de resistir ou facilitar os processos morfológicos e pedogenéticos, atribuídos valores que variavam entre 1 (para áreas estáveis) e 3 (para áreas vulneráveis) de acordo com os valores estabelecidos por Crepani et al. (2001). Posteriormente, com os mapas ponderados, seguiu-se para a aplicação da Equação 1:

$$
U P N=\frac{G+R+S+V g+C}{5}
$$

Onde: $\mathrm{UPN}=$ Unidades de Paisagem Natural, $\mathrm{G}=$ Geologia, $\mathrm{R}=$ Geomorfometria, $\mathrm{S}=$ Solos, Vg = Vegetação Potencial e C = Clima.

Vulnerabilidade Ambiental - Corresponde à vulnerabilidade à perda de solo de uma determinada área baseada na análise empírica dos elementos dos meios físico e antrópico da mesma.Este mapa foi elaborado a partir do cruzamento matricial entre os mapas de Unidade de Paisagem Natural (UPN) e Uso e Cobertura da Terra.

Primeiramente foi elaborado o mapa Uso e cobertura da Terra a partir da imagem Landsat-8, orbita/ponto 225/75 de 16 de Abril de 2015 (USGS, 2016). A metodologia de tratamento e classificação da imagem seguiu Moreira (2012) e as classes de uso e cobertura da terra foram obtidas em IBGE (2013): (1) Pastagem: Pecuária Bovina; (2) Vegetação Natural: Formação Florestal; (3) Vegetação Natural: Formação Campestre; (4) Áreas Urbanizadas: Cidade; (5) Águas Continentais.

O Mapa de Uso e Cobertura da Terra foi ponderado seguindo-se os valores de vulnerabilidade de Crepani et al. (2001) e Almeida e Soares Filho (2015). Após a ponderação, foi realizado o Cruzamento Matricial com o mapa de UPNs (Equação 2): 


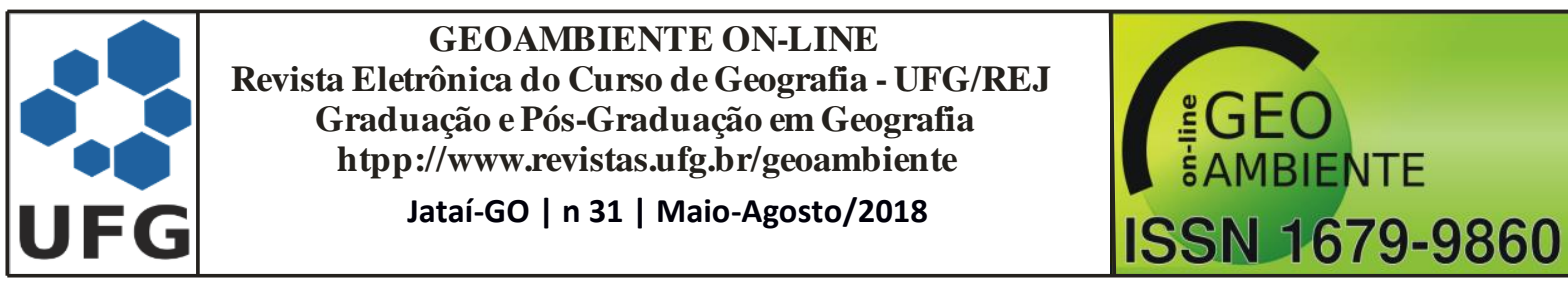

$$
V=\frac{U P N+P}{2}
$$

Onde: $\mathrm{V}=$ Vulnerabilidade, $\mathrm{UPN}=$ Unidades de Paisagem Natural e $\mathrm{P}=\mathrm{Uso}$ e Cobertura da Terra

Unidades de Paisagem Legal (UPL) - Foi obtido através do cruzamento matricial entre o mapa de Uso e Cobertura da Terra e o mapa de Legislação Ambiental e demonstra conformidade ou desconformidade da área de estudo em relação a cobertura vegetal de determinada pelo Código Florestal Brasileiro (BRASIL, 2012).

O mapa de Uso e Cobertura da Terra foi reclassificado, em: Áreas Naturais e Áreas Antrópicas, e ponderado, respectivamente, em 1 e 2.

O Mapa de Legislação Ambiental especializa as Áreas de Preservação Permanente da bacia e foi elaborado a partir do mapa de distâncias que correspondessem as áreas de Áreas de Preservação Permanentes determinadas por Brasil (2012) gerado a partir da rede de drenagem e das nascentes vetorizadas sobre a imagem Landsat 8. Posteriormente, esse mapa de distância foi convertido em matriz, e classificado em: Com APP e Sem APP, (ponderados respectivamente com valores: 10 e 20).

Fez-se então o cruzamento entre os mapas de Legislação Ambiental e Uso e Cobertura da Terra Reclassificado, com objetivo de apontar se as áreas de APP estavam sendo respeitadas. Durante o cruzamento, o primeiro dígito da matriz correspondia ao Mapa de Legislação e o segundo digito ao mapa de Uso e Cobertura da Terra. Dessa forma, a matriz de cruzamento apresentava quatro possibilidades $(11,12,21$ e 22) sendo que três dessas possibilidades foram classificadas como Regular (11, 21 e 22), pois obedeciam a legislação, e uma possibilidade foi classificada como Irregular (12), porque a legislação era desrespeitada. Dessa forma o mapa final apresentou duas classes: Regular e Irregular.

Zoneamento Ambiental - Caracteriza a área de estudo quanto a sua Vulnerabilidade Ambiental e conformidade com o Código Florestal. Para elaboração do mapa de Zoneamento realizou-se o cruzamento entre os mapas de Vulnerabilidade Ambiental e Unidades de Paisagem Legal. Neste cruzamento buscou-se identificar qual o grau de vulnerabilidade e a conformidade quanto as áreas de APP. Dessa forma, o primeiro dígito correspondia as classes de Vulnerabilidade e o segundo dígito as classes de UPL A partir da grade resultante 


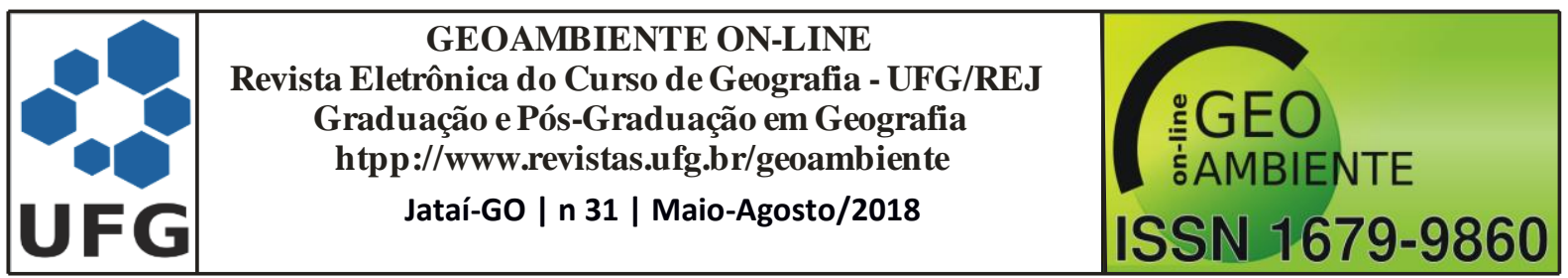

realizou-se um fatiamento dos valores, para obter as seguintes classes (Quadro 1):

Quadro 1: Classes de Zoneamento.

\begin{tabular}{|l|l|}
\hline Zonas & Características da Classe \\
\hline Zona de Conservação & $\begin{array}{l}\text { Áreas Estáveis à Medianamente Estável/Vulnerável em } \\
\text { conformidade com a legislação. }\end{array}$ \\
\hline Zona de Manejo Racional & $\begin{array}{l}\text { Áreas Moderadamente Vulneráveis em conformidade com a } \\
\text { legislação. }\end{array}$ \\
\hline Zona de Recuperação & $\begin{array}{l}\text { Áreas Vulneráveis em conformidade com a legislação, } \\
\text { necessitando prevenir e mitigar os processos erosivos. }\end{array}$ \\
\hline Zona de Regularização & $\begin{array}{l}\text { Áreas, independente da vulnerabilidade, em } \\
\text { desconformidade com a legislação. }\end{array}$ \\
\hline
\end{tabular}

\section{RESULTADOS E DISCUSSÕES}

As Unidades de Paisagem Natural (UPN) são "uma porção do terreno onde se inscreve uma combinação de eventos e interações, visíveis e invisíveis" (CREPANI et al., 2001). Essas unidades representam a vulnerabilidade natural de uma determinada área à perda de solo através da combinação entre a Geomorfologia, o Clima, a Geologia, o Solo e a Vegetação Potencial.

Hidrografia e Relevo - A bacia hidrográfica do córrego apresenta rede de drenagem dentrítica, com baixa amplitude altimétrica (144m de amplitude, variando entre 128 e 273 m de altitude, sendo que 55,4\% da área encontra-se entre 167 e $207 \mathrm{~m}$ de altitude), sendo que as mais altas altitude correspondem a região sul, sudoeste e leste da bacia.

A Depressão do Miranda/Aquidauana é a compartimentação geomorfológica em que a bacia está inserida, ocupando toda sua extensão. Segundo Brasil (1997), essa formação geomorfológica apresenta majoritariamente formas de relevo tabulares, de topo plano separados por vales de fundo plano. Mato Grosso do Sul (1990) afirma que a Depressão do Miranda faz parte de uma compartimentação geomorfológica maior, a Depressão do Alto Paraguai, e sua origem está ligada a abatimentos tectônicos e a processos de pediplanação.

O relevo é suave ondulado, em que declividades entre 2 e $6 \%$ são predominantes. A declividade máxima é de $20 \%$, observada nas áreas de divisores de águas entre as micro bacias. A Amplitude Altimétrica atinge até $40 \mathrm{~m}$ de entalhamento, mas entalhamento inferiores a $20 \mathrm{~m}$ correspondem a mais de $75 \%$ da área. O mais representativo elemento da análise da Geomorfometria é a Amplitude Interfluvial, que possui maior variação, sendo que as áreas mais dissecadas correspondem as micro bacias dos córregos Picada e Capim Branco, na região leste e 


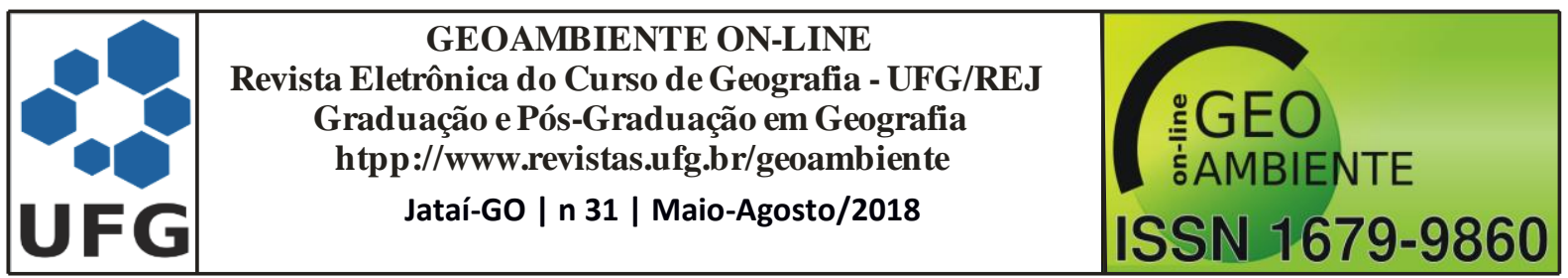

noroeste da bacia. A partir desses parâmetros do relevo, entende-se que a energia do relevo nesta bacia hidrográfica é baixa, podendo favorecer os processos pedogenéticos.

Geologia - As formações geológicas encontrados na bacias correspondem a rochas sedimentares de idade Paleozóica (Grupo Itararé - Formação Aquidauana, composto por arenitos), Quaternárias (Formação Pantanal, constituída por depósitos fluviais e lacustres, oriundos de áreas periodicamente inundáveis e/ou sujeitos a inundações ocasionais) e Holocênicas (Aluviões Fluviais, que ocorrem descontinuamente ao longo dos principais canais de drenagem) e rochas metamórficas de idade Neoproterozóica (Grupo Cuiabá - constitui-se majoritariamente de filitos) (CPRM, 2001).

Clima - Para Embrapa (2012), o clima na área abrangida pela bacia do córrego Acôgo possui temperaturas médias elevadas mesmo no inverno, quando se mantém acima de $18^{\circ} \mathrm{C}$. As precipitações encontram-se entre $750 \mathrm{~mm}$ e $1800 \mathrm{~mm}$ anuais, com estação seca variando de 3 à 4 meses (entre maio e setembro), período no qual os totais mensais pluviométricos são inferiores à 50mm. Nessas condições e com o valor de Intensidade Pluviométrica de 527.3, segundo Crepani et al. (2001) o grau de vulnerabilidade/estabilidade para a área é de 3.0, considerado Vulnerável.

Vegetação Potencial - Corresponde a formações de Cerrado, apresentando tanto formações Campestres e Florestadas: Savana Parque - (Campo Sujo), Savana Arbórea Densa (Cerradão), Floresta Aluvial; Formações de encraves e ecótonos: Contato Savana/Floresta Estacional e Contato Savana Estépica/Floresta Estacional. A formação mais abrangente é Savana Parque (Campo Sujo), que corresponde a uma formação campestre com estrato de árvores baixas, geralmente com alturas de 2 à 3 metros, quase sempre de uma mesma espécie (MATO GROSSO DO SUL, 1990).

Solos - Observa-se a presença de solos bem desenvolvidos e profundos como o Argissolo Vermelho-Amarelo e o Latossolo Vermelho (que somados chegam a 85\% da área total da bacia), e a presença de solos pouco desenvolvidos como o Gleissolo Háplico e o Neossolo Regolítico, altamente vulneráveis aos processos erosivos (MATO GROSSO DO SUL, 1990), são encontrados respectivamente próximo ao canal de drenagem principal da bacia, o córrego Acôgo, e na região extremo leste da bacia, no alto curso.

A análise dos elementos da paisagem permitiu aferir que as condições naturais da bacia favorecem os processos morfogenéticos, em detrimento aos processos pedogenéticos, fato 


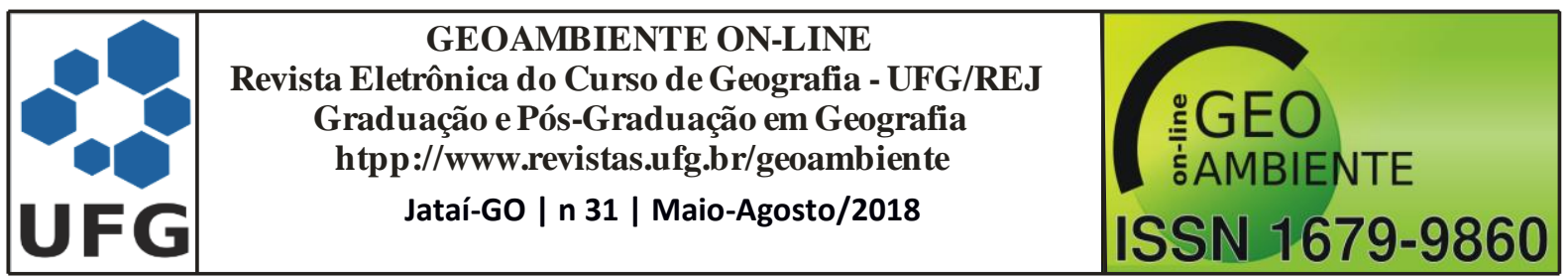

plausível para uma bacia localizada no ecótono entre Planície e Planalto, que possui intensa dinâmica de deposição de sedimentos e características de pene-plano (Figura 3).

Figura 3: Unidades de Paisagem Natural da bacia hidrográfica do córrego Acôgo-MS
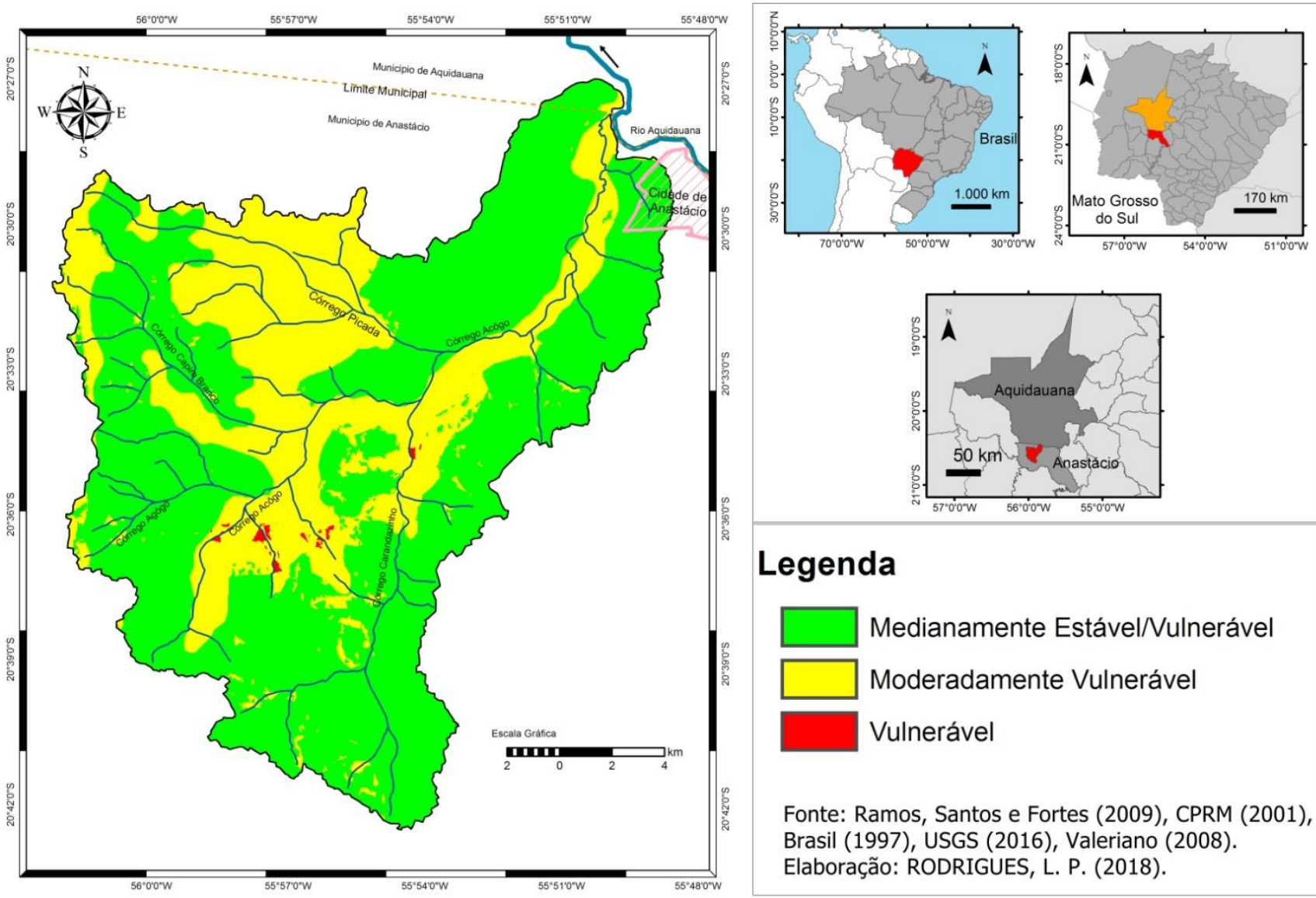

\section{Legenda}

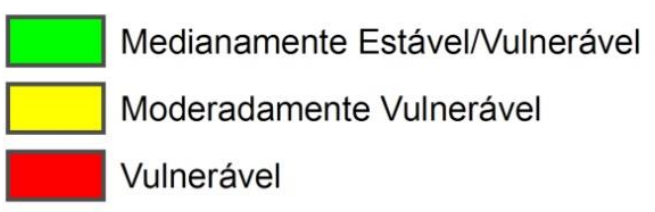

Fonte: Ramos, Santos e Fortes (2009), CPRM (2001), Brasil (1997), USGS (2016), Valeriano (2008). Elaboração: RODRIGUES, L. P. (2018).

Organização: Rodrigues, L.P (2018).

A classe Medianamente Estável/Vulnerável, que ocupa $242.3 \mathrm{~km}^{2}$ ou $66.80 \%$, e destacase principalmente a presença de vegetação arbórea de savana, Latossolos e Argissolos, além da existência da Formação Geológica Grupo Itararé - Formação Aquidauana. Tal combinação garante maior proteção contra a erosão, pois apresenta solos mais estáveis, vegetação densa e extrato geológico formado principalmente por arenitos, considerados moderadamente vulneráveis, assim como o relevo, que apresenta-se suave e pouco dissecado.

A classe Moderadamente Vulnerável ocupou $119.6 \mathrm{~km}^{2}$, ou $32.97 \%$ da área total. Nesta classe destacam-se a presença de áreas abrangendo a Formação Geológica Pantanal e Depósitos Aluviais, altamente vulneráveis e a existência de cobertura vegetal arbustiva, além de solos Glei. Cada um desses elementos associados ao clima considerado vulnerável e regiões de relevo mais dissecado proporcionam grau de vulnerabilidade moderado. 


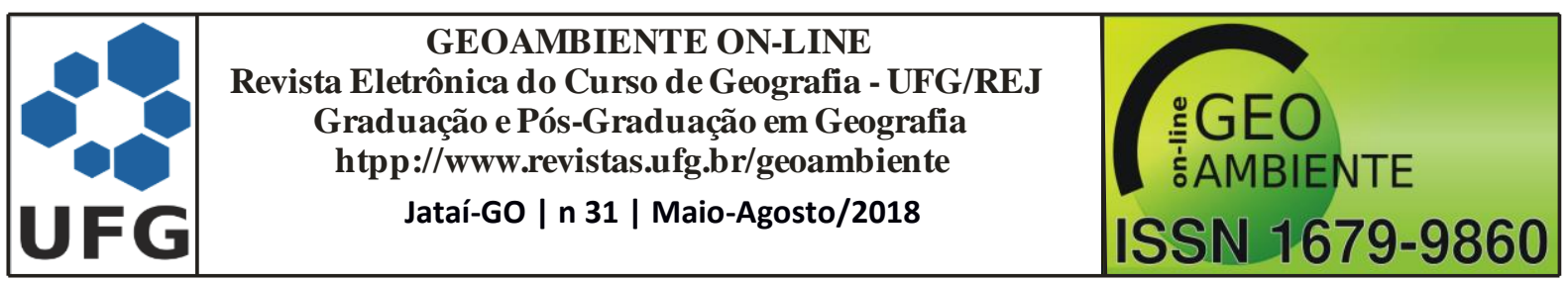

A classe Vulnerável ocupa apenas $0.8 \mathrm{~km}^{2}$ ou $0.23 \%$ da área de estudo. Nessa classe, encontram-se às áreas com ocorrência de Gleissolos, substrato de Depósitos Aluviais, Vegetação Arbustiva e mais altas declividades, amplitudes altimétricas, além das maiores amplitudes interfluviais da bacia.

Uso e Cobertura da Terra - A cobertura da terra evidencia os usos do qual decorre, podendo tanto ajudar a controlar e prevenir os processos erosivos e degradantes, quanto facilitar que eles ocorram (SILVA, 1999). Na Bacia Hidrográfica do Córrego Acôgo, a principal atividade econômica é a pecuária extensiva de gado de corte e leite, evidenciada a partir da análise do mapa de Uso e Cobertura da Terra (Figura 4), que apresenta grande difusão de pastagens pela bacia.

Figura 4: Uso e Cobertura da Terra da bacia hidrográfica do córrego Acôgo-MS

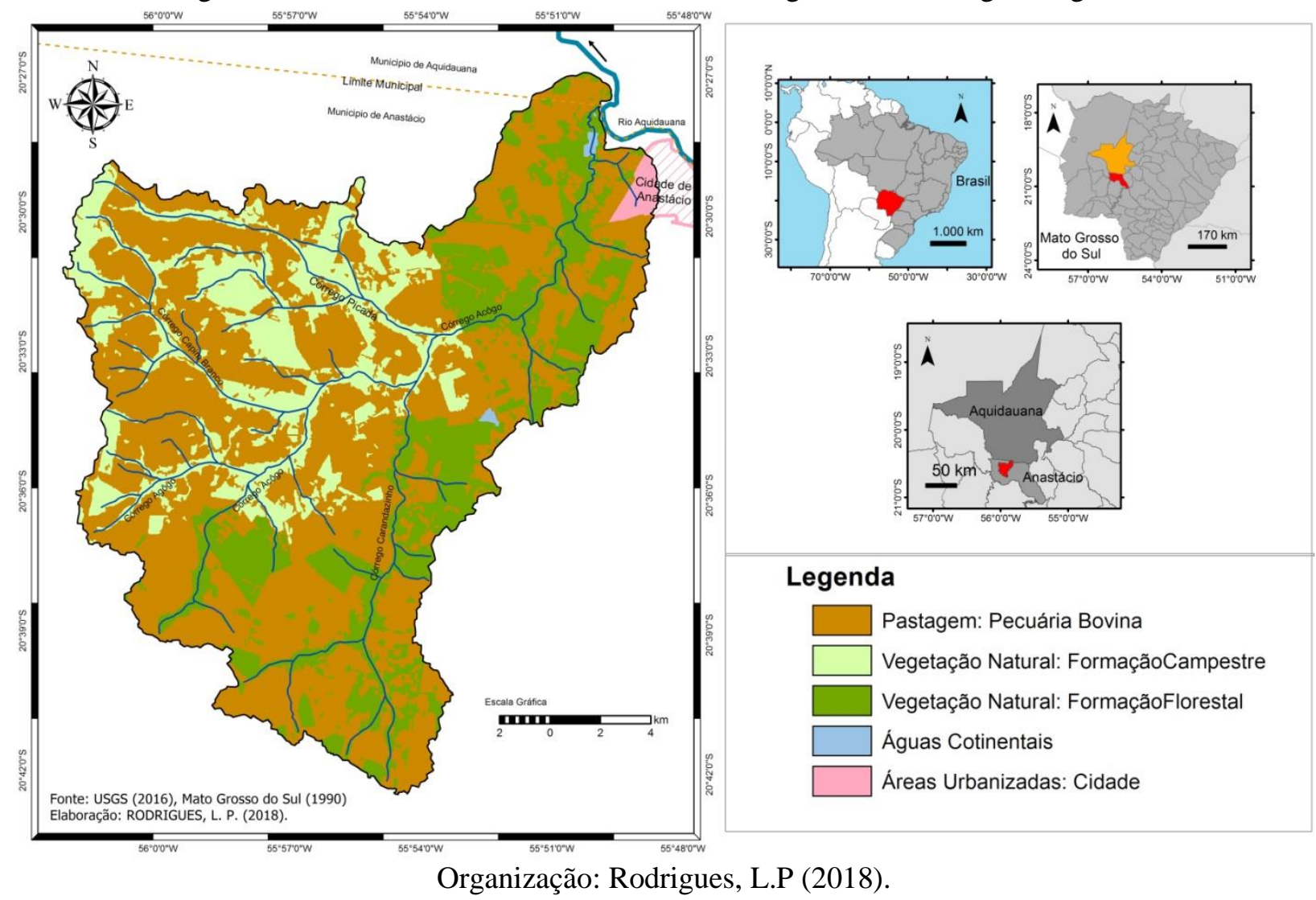

A classe Pastagem: Pecuária Bovina ocupou $60.23 \%$ da bacia (Tabela 1). A pastagem avançou até mesmo em áreas de preservação permanente substituindo as matas ciliares, áreas de nascente e deixando desprotegidas as áreas úmidas. 


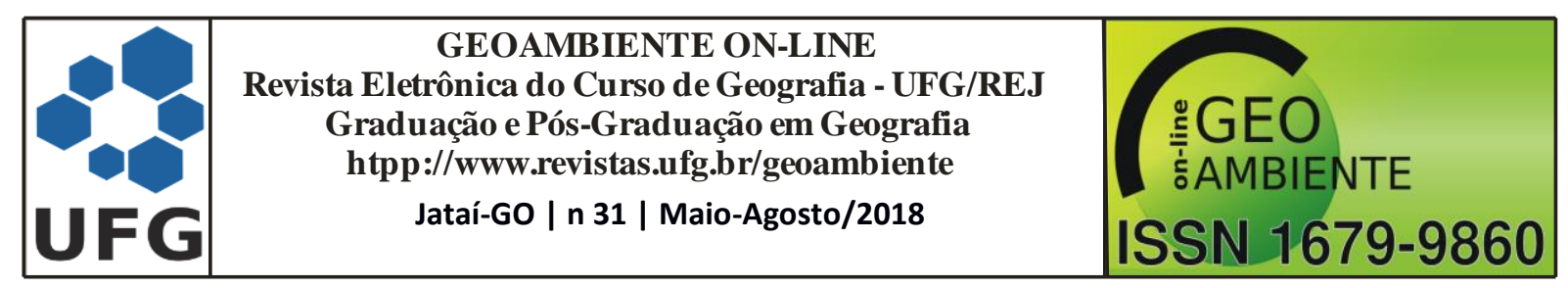

Tabela 1: Classes de Uso e Cobertura da Terra

\begin{tabular}{l|l|l}
\hline Classe & Área $\left.\mathbf{( k m}^{\mathbf{2}}\right)$ & $\mathbf{\%}$ \\
\hline Pastagem: Pecuária Bovina & 218,8 & 60,25 \\
\hline Vegetação Natural: Formação Florestal & 75 & 20,7 \\
\hline Vegetação Natural: Formação Campestre & 65,5 & 18,11 \\
\hline Áreas Urbanizadas: Cidade & 2,6 & 0,72 \\
\hline Águas Continentais & 0,8 & 0,22 \\
\hline Total & 362,7 & 100 \\
\hline
\end{tabular}

A remoção da vegetação nativa para a inserção de pastagens modifica a dinâmica ambiental em bacias hidrográficas, uma vez que essa substituição prejudica a infiltração da água no solo, além da utilização dessas áreas pelo gado promove a compactação do solo e cria caminhos preferenciais para o escoamento superficial, aumentando o risco de erosão. Esses caminhos são criados principalmente em direção aos córregos, pois os animais utilizam-se dessas águas para dessedentação.

A Figura 5 (A e B) mostram respectivamente áreas de preparo para o plantio de pastagem e áreas já utilizadas para pastoreio do gado na bacia. Essas áreas passaram pelo processo de gradeamento, onde o solo é revolvido e exposto para facilitar plantio dessas forrageiras exóticas, destacadamente Brachiarias (Brachiaria Decumbens, Brachiaria Humidicola).

Figura 5: Solo exposto (A) e gado bovino (B) no médio curso da bacia do córrego Acôgo

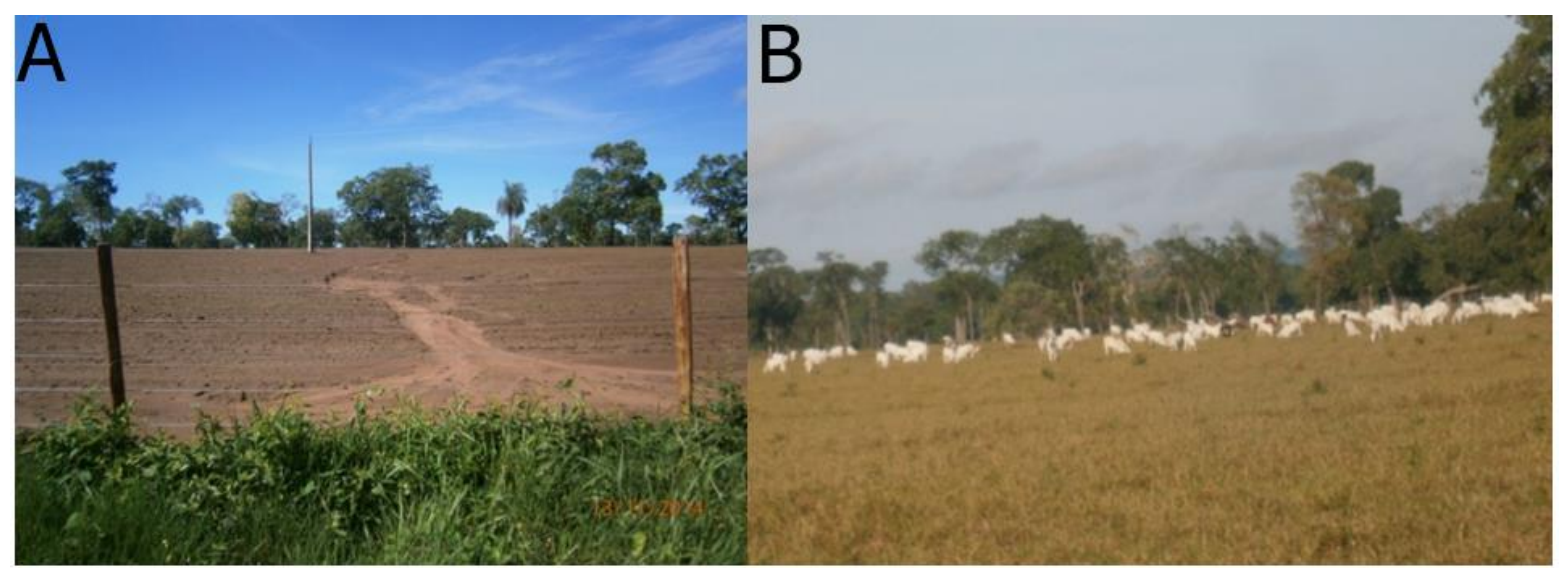

Foto: Rodrigues, L. P. (2014).

Mafra (2005) aponta que, essas atividades, quando não realizadas de acordo com as necessidades dos ambientes naturais geram desequilíbrio, acarretando processos erosivos, e diminuição de sua capacidade de sustentação para os organismos vivos. Diante do Exposto, 


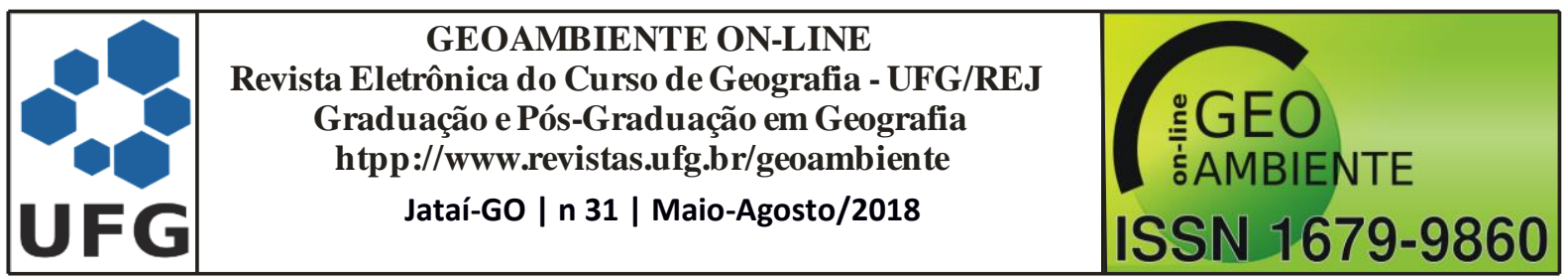

considera-se que o Uso e Cobertura da Terra podem gerar modificações significativas para os geossistemas, necessitando, assim, de planejamento a longo prazo para minimizar a degradação.

Segundo Cappi (2002), a pecuária, juntamente com a agricultura, é indispensável do ponto de vista socioeconômico, pois representam o setor de produtos alimentícios, contudo, os impactos ambientais gerados por essas atividades causam preocupação, pois favorecem os processos erosivos e a contaminação das águas superficiais e subterrâneas.

O avanço da pastagem na bacia hidrográfica do córrego Acogo, pode ser justificada pela facilidade na ocupação de seus terrenos, no entanto, tal característica não elimina a necessidade de utilização de técnicas conservacionistas e a manutenção da vegetação ciliar, sendo tais práticas não observadas na área durante o trabalho de campo realizado.

Vulnerabilidade Ambiental - A Bacia Hidrográfica do Córrego Acôgo-MS apresenta expressiva vulnerabilidade ambiental, cerca de $77.5 \%$ de sua área possui valor de vulnerabilidade superior 2.3. As áreas naturalmente mais vulneráveis da bacia encontram-se ás margens do principal córrego da bacia, o Acôgo, e na região noroeste da bacia, devido principalmente à presença de Gleissolos, formação de Depósitos Aluviais e sedimentos da Formação Pantanal e a existências de Vegetação Campestre, além da Intensidade Pluviométrica que é elevada em toda a bacia. Os resultados expressados pela Figura 6 apontam uma elevação da vulnerabilidade da área de estudo quando comparado ao mapa de Unidades de Paisagem Natural, demonstrando o papel determinante da ação antrópica.

No trabalho de campo realizado em 13 de novembro de 2014, puderam-se observar diversos pontos de erosão. Destaca-se que às margens da BR 262, nas estradas vicinais da bacia e nas propriedades rurais vizinhas a erosão é visível, afetando até mesmo a circulação de veículos, e nas propriedades rurais adjacentes às vias públicas podem ser vistas voçorocas. Essa situação é ilustrada nas imagens a seguir representa a associação entre vulnerabilidade natural da bacia do Acôgo e dos usos nela existente (Figura 7 - A, B e C). 


\begin{tabular}{|c|c|c|}
\hline & $\begin{array}{c}\text { GEOAMB IENTE ON-LINE } \\
\text { Revista Eletrônica do Curso de Geografia - UFG/REJ } \\
\text { Graduação e Pós-Graduação em Geografia } \\
\text { htpp://www.revistas.ufg.br/geoambiente } \\
\text { Jataí-Go | n } 31 \text { | Maio-Agosto/2018 }\end{array}$ & $\begin{array}{c}\text { : MEO } \\
\text { G }\end{array}$ \\
\hline
\end{tabular}

Figura 6: Vulnerabilidade Ambiental da bacia hidrográfica do córrego Acôgo-MS
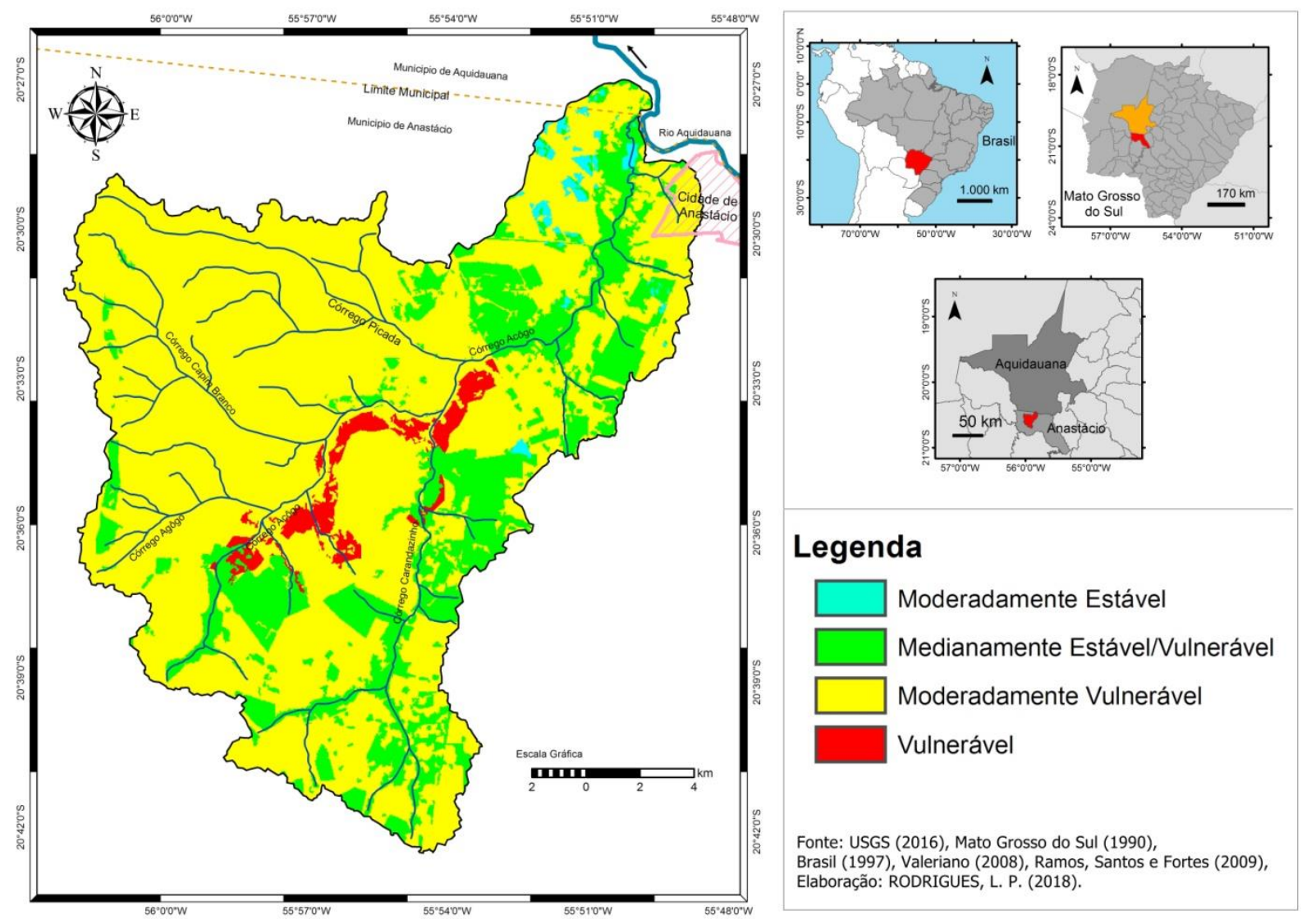

Organização: Rodrigues, L.P (2018).

Figura 7: Processos erosivos na bacia hidrográfica do córrego Acôgo-MS

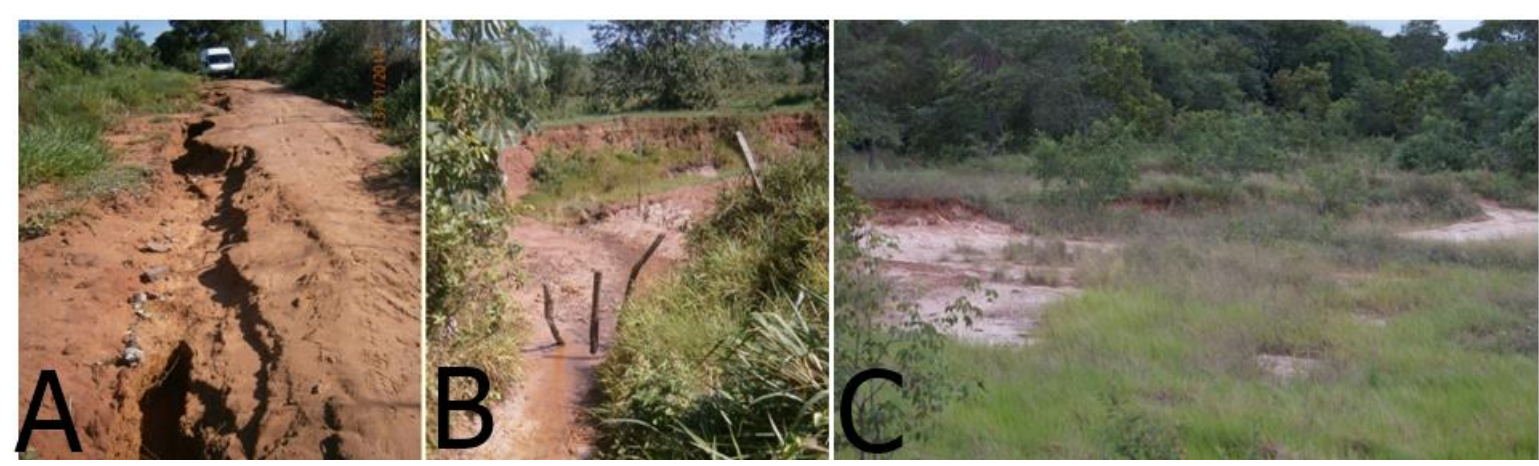

Foto: Leite, E. F. (2016); Rodrigues, L.P. (2014).

Unidades de Paisagem Legal - Nesta bacia, 22.76\% das Áreas de Preservação Permanentes estão sendo desrespeitadas, descumprindo a Legislação Federal (Figura 8).

No mapeamento foram identificados dois tipos de irregularidades, remoção da vegetação para a inserção de pastagem e para a instalação de adensamento urbano. A partir da análise do 


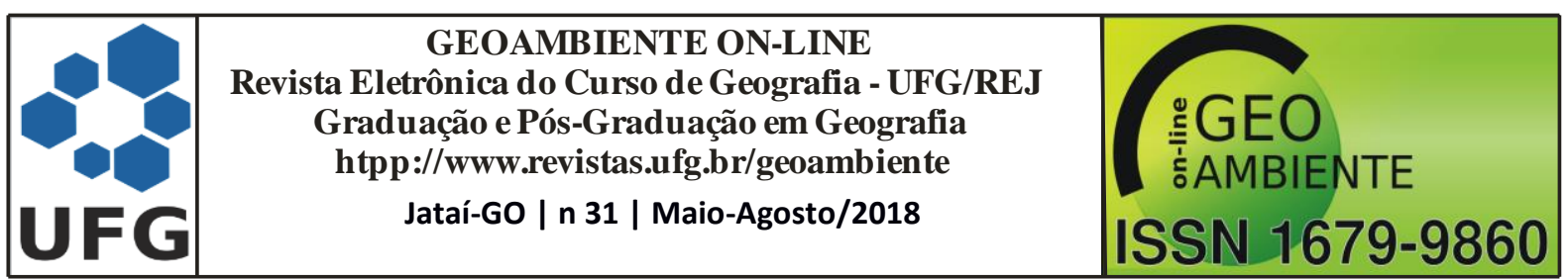

mapa, observa-se que 24, das 41 nascentes da bacia (58.5\%) encontram-se desprotegidas, tendo sua vegetação suprimida para dar lugar a pastagens (23 nascentes) e à área urbana (uma nascente). Dentre todos os córregos da bacia, apenas um córrego (de primeira ordem), tem toda a sua APP preservada. Os demais têm pelo menos um ponto em que a cobertura vegetal foi removida.

Figura 8: Unidades de Paisagem Legal da bacia hidrográfica do córrego Acôgo-MS
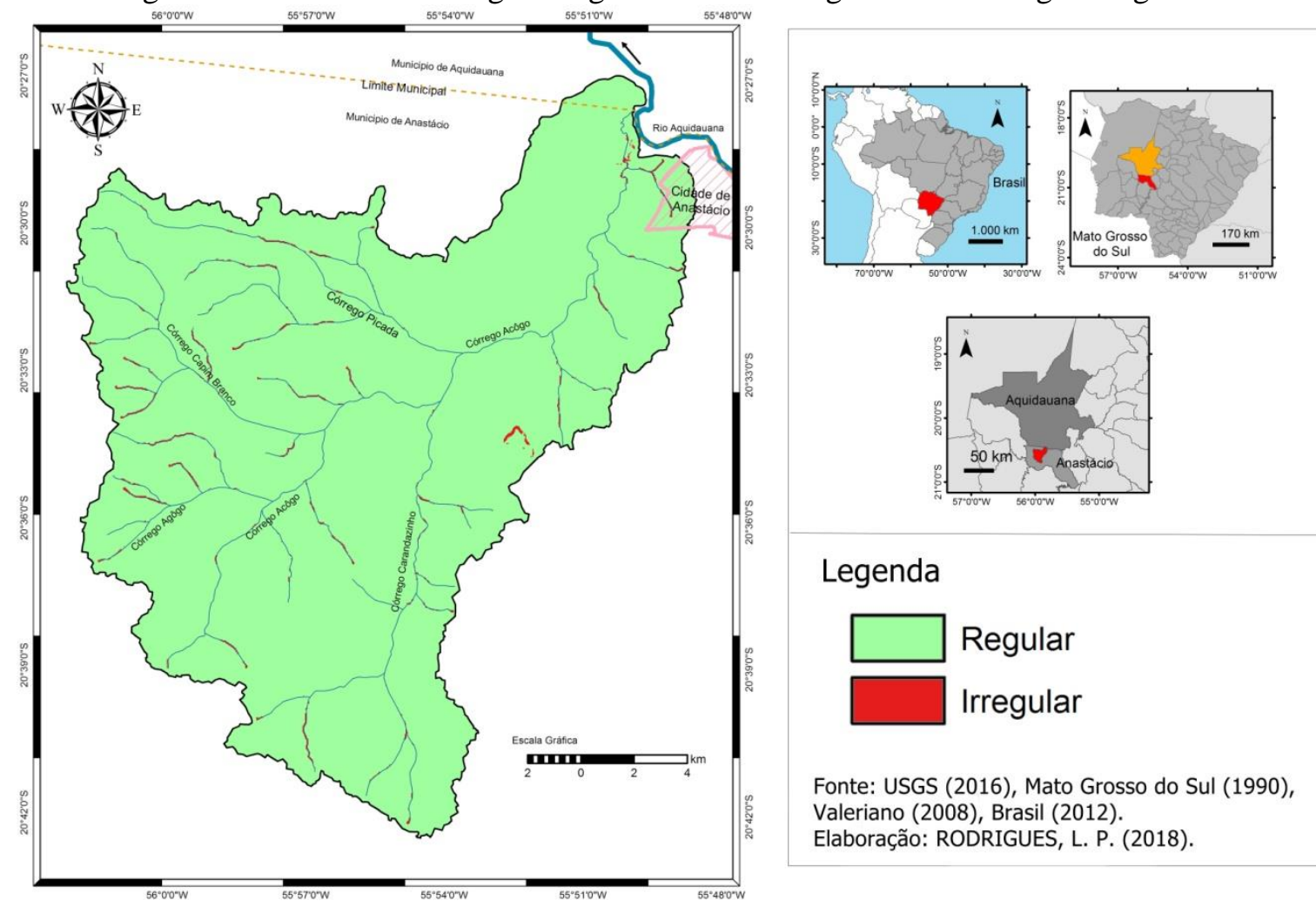

Fonte: USGS (2016), Mato Grosso do Sul (1990), Valeriano (2008), Brasil (2012). Elaboração: RODRIGUES, L. P. (2018).

Organização: Rodrigues, L.P (2018).

Os afluentes dos Córregos Capim Branco, Picada e Agôgo, localizados na porção oeste e noroeste da bacia, são os que apresentam as maiores áreas com irregularidades. Nesta região naturalmente vulnerável (principalmente devido à presença de litologias frágeis como a Formação Pantanal e a formação de Aluviões Fluviais, Vegetação Campestre, e no alto curso da bacia (cabeceira de nascentes) a presença de Neossolos), o não cumprimento das restrições legais podem ter repercussões em toda a bacia, favorecendo o assoreamento dos córregos e prejudicando a qualidade da água.

Observa-se, também, que córregos próximos à foz do Acôgo, tem quase toda sua área de APP desrespeitada. Destaca-se nessa análise que o córrego principal, o Acôgo, tem quase toda sua 


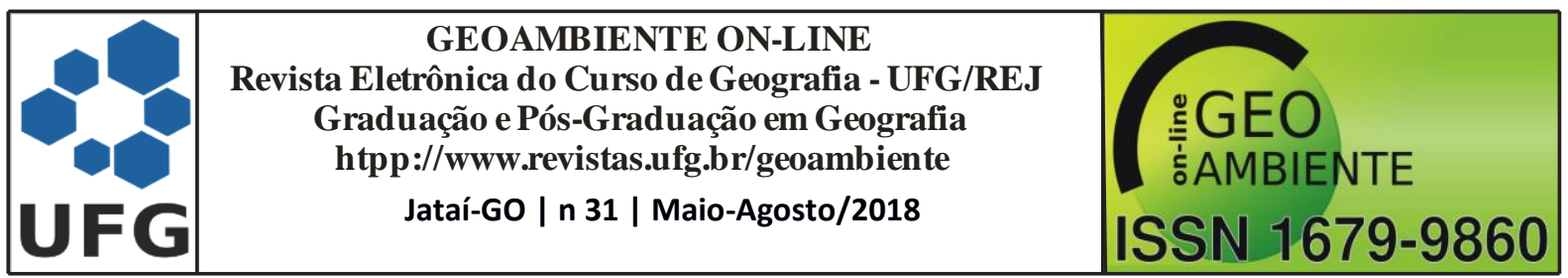

área de APP preservada, o que, contudo, não pode garantir a qualidade da água, visto que seus afluentes encontram-se em situação irregular.

Ao remover a vegetação nativa dessa bacia naturalmente vulnerável, e diminuir a proteção contra os processos erosivos, principalmente nas áreas de APP desrespeitadas, se favorece o assoreamento dos canais de drenagem e deterioração da qualidade da água, principalmente devido à inserção de pastagens para o desenvolvimento da pecuária bovina extensiva, que acarreta ainda no pisoteamento do solo, que o compacta, e seus excrementos, que poluem as águas.

Zoneamento Ambiental - As características da bacia levam à reflexões sobre a necessidade do estabelecimento de um planejamento que busque compatibilizar os diversos interesses dos campos socioeconômico e ambiental, visando alcançar um desenvolvimento sustentável. O Zoneamento Ambiental elaborado pode ser entendido como um subsidio para essas ações de planejamento. As quatro zonas estabelecidas buscam atingir esses objetivos, apontando as características comuns das zonas e fazendo proposições (Figura 9).

Zona de Regularização - Ocupam $0,8 \%$ da área total da bacia. São de fundamental necessidade à manutenção do ciclo hidrológico e devido à legislação ambiental vigente são de emergencial recuperação da vegetação ciliar, fazendo-se cumprir a legislação ambiental.

Zona de Conservação - Ocupam $22.5 \%$ da área e tem relevância para a bacia por fornecerem proteção contra os processos erosivos, realizando funções sistêmicas e ecológicas, auxiliando na conservação da fauna e flora da bacia, e participando do ciclo hidrológico através dos processos biológicos e físicos que realizam. Essas áreas devem ter sua cobertura vegetal mantida.

Zona de Recuperação - representam áreas vulneráveis aos processos erosivos devido às suas características naturais e acentuadas pela ação antrópica, sendo a recuperação de sua vegetação aconselhável, pois a ausência de proteção pode acarretar em graves problemas erosivos futuros e intensificação dos processos atualmente em curso, interferindo no equilíbrio da bacia inteira, uma vez que esta zona ocupa $2.6 \%$ da bacia, localizados linearmente próximo ao principal canal de drenagem, o córrego Acôgo, na região de seu alto e médio curso. 


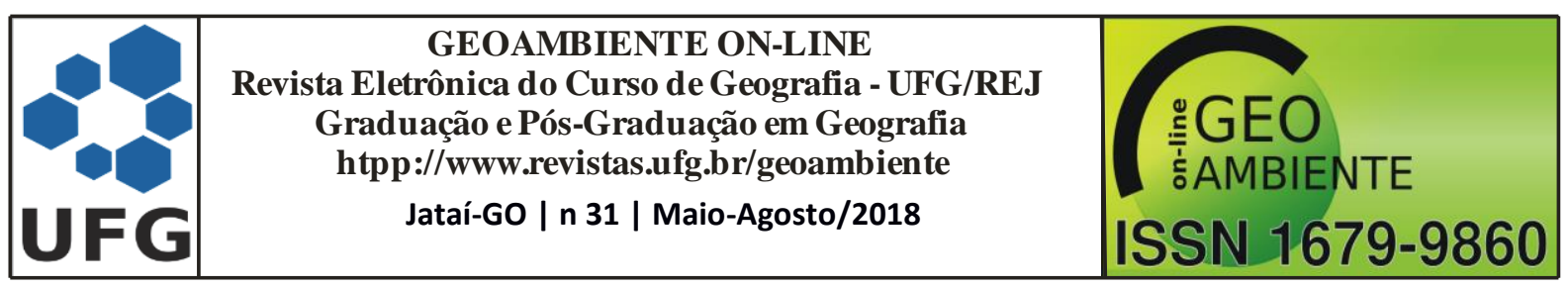

Figura 9: Zoneamento Ambiental da bacia hidrográfica do Córrego Acôgo-MS
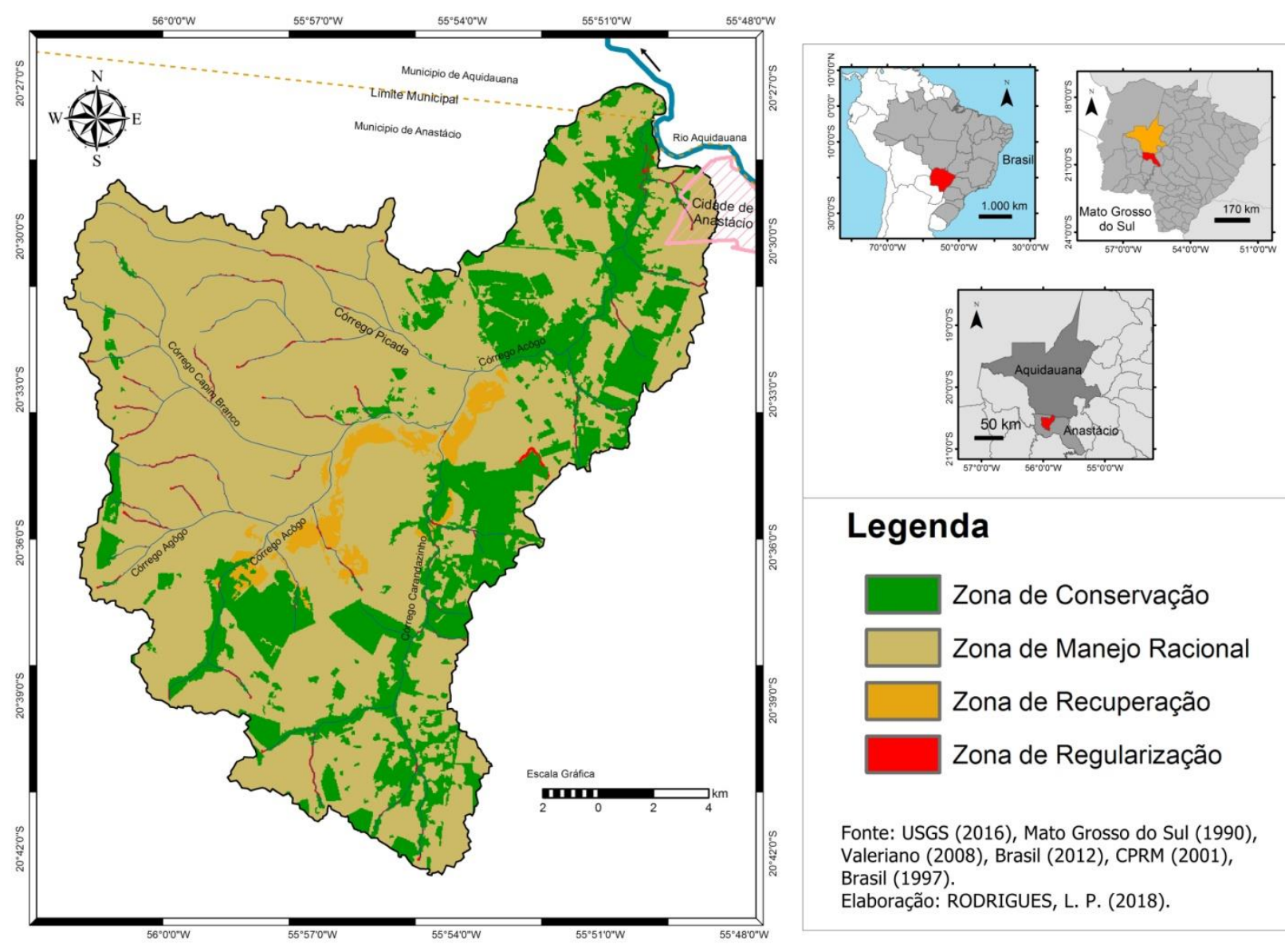

\section{Legenda}

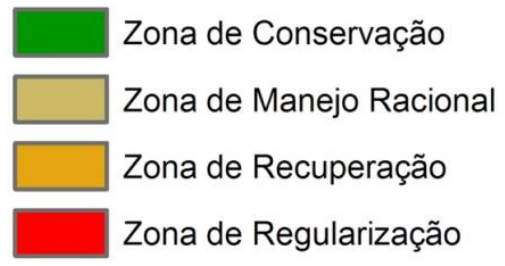

Fonte: USGS (2016), Mato Grosso do Sul (1990), Valeriano (2008), Brasil (2012), CPRM (2001), Brasil (1997).

Elaboração: RODRIGUES, L. P. (2018).

Organização: Rodrigues, L.P (2018).

Zona de Manejo Racional - são as mais representativas (74.1\% da área) e heterogêneas da bacia. A utilização intensa da área tem coma base a pecuária, nesse sentido, a necessidade de adoção de manejos sustentáveis é eminente visando-se tornar possível a realização da atividade, não apenas no presente, mas no futuro. Essas atividades econômicas precisam se adaptar as condições existentes na área, para que não sejam impossibilitadas devido degradação dos principais recursos naturais por ela utilizados: o solo e a água.

\section{CONSIDERAÇÕES FINAIS}

O Zoneamento Ambiental realizado classifica a paisagem da bacia hidrográfica do Córrego Acôgo em diferentes níveis de estabilidade e vulnerabilidade ambiental, e apresenta de forma sintética, mapas e informações, subsídios a ocupação racional e preservação dos espaços de maneira equilibrada. Contribui-se, desta maneira, para os estudos ambientais de abordagem de 


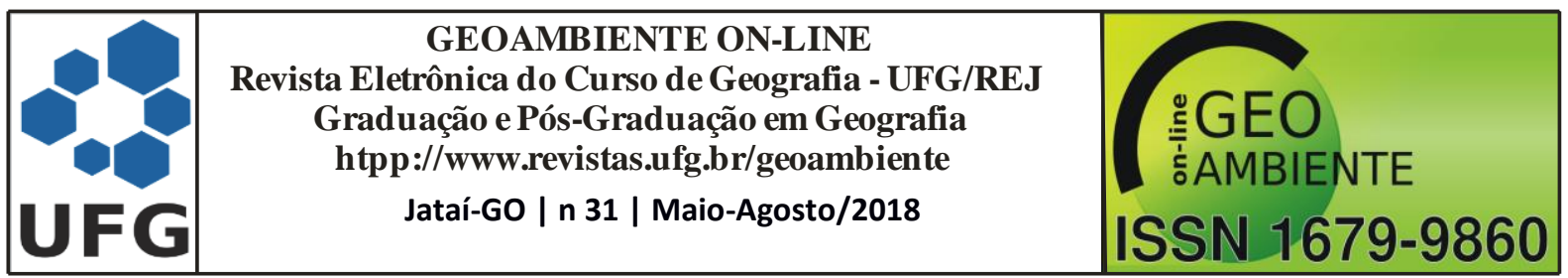

paisagem integrada, aplicação e adaptação de metodologias de Zoneamento e Vulnerabilidade Ambiental.

Diante do exposto, em relação a situação ambiental apresentada para a área sugere-se a manutenção de remanescentes florestais, bem como a recomposição florestal, notadamente das áreas de maior vulnerabilidade, dada a importância da cobertura vegetal a estabilidade dos ambientes naturais. Áreas incorporadas ao processo produtivo da bacia devem adotar no processo de exploração do meio, práticas edáficas-mecânicas-vegetativas, para sustentabilidade do solo e da água. Estas, por sua vez, as práticas de pecuária, que obedeçam os limites naturais destas paisagens para delas prosperarem como atividades econômicas rentáveis e sustentáveis ao longo do tempo.

\section{REFERENCIAS}

ALMEIDA, R. B. de.; SOARES FILHO, A. Susceptibilidade erosiva no município de Bodoquena - Mato Grosso do Sul. In: Simpósio Brasileiro de Geografia Física Aplicada, XVI, Teresina - PI, Anais... Teresina - PI: UFPI, 2015, p.1085-1093. CD-ROM.

BACANI, V. M.; LUCHIARI, A. Geoprocessamento aplicado ao zoneamento ambiental da bacia do alto rio coxim-ms. GeoUSP Espaço e Tempo, São Paulo, v.18, n.1, p. 184-197, 2014. Disponível em: https://goo.gl/mtQfUC. Acesso em: 05jun.2018.

BARROSO, L.B.; TREVISAN, T. M.; WOLFF, D. B. Proposta de zoneamento ambiental para município de Itaara - RS. Engenharia Ambiental, Espírito Santo do Pinhal, v. 12, n. 01 p. 123 136, 2015. Disponível em: https://goo.gl/bZbyfa. Acesso em 05jun.2018.

BRASIL. Código Florestal Brasileiro. Lei 12.651, de 25 de maio de 2012. Brasília - DF: Planalto, 2012. Disponível em: http://goo.gl/fTaojV. Acesso em: 30jan.2016.

BRASIL. Ministério do Meio Ambiente. Plano de Conservação da Bacia do alto Paraguai (Pantanal), PCBAP. Brasília - DF: MMA, 1997.

BRASIL. Ministério do Meio Ambiente. Política Nacional de Recursos Hídricos. Lei no 9.433, de 8 de Janeiro de 1997. Disponível em: http://goo.gl/O9gACx. Acesso em: 30jan.2016.

BRASIL. Política Nacional do Meio Ambiente. Lei no 6938, de 31 de Agosto de 1981. Disponível em: http://goo.gl/wbr6Ms. Acesso em: 30jan.2016.

CAPPI, N. Implicações do Uso e Ocupação do Solo na qualidade das águas subterrâneas das bacias dos córregos Fundo e Santa Maria/MS. 2002. 113fls. Dissertação (Mestrado em Geografia) - Universidade Federal de Mato Grosso do Sul, Dourados-MS. 


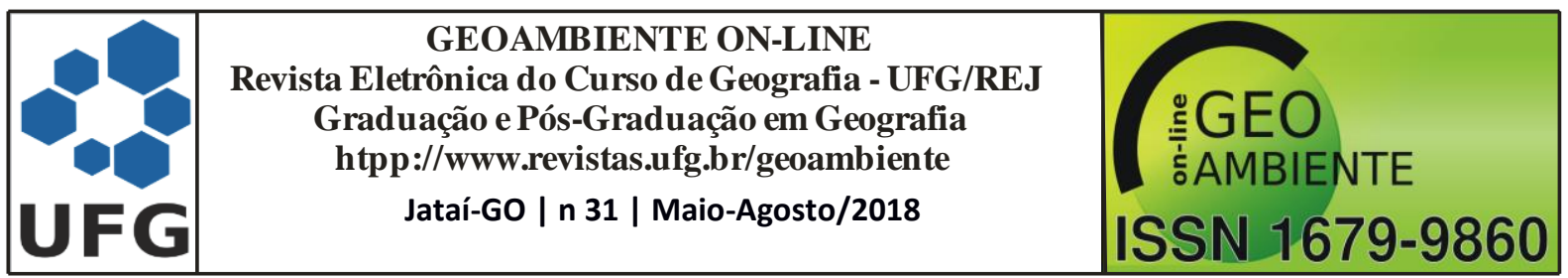

CARVAlHO, R. G. de. As bacias hidrográficas enquanto unidades de planejamento e zoneamento ambiental no Brasil. Caderno Prudentino de Geografia, Presidente Prudente, n.36, Volume Especial, p. 26-43, 2014. Disponível em: https://goo.gl/mPik8a. Acesso em 05jun.2018.

CPRM. Programa Levantamentos Geológicos Básicos do Brasil. Corumbá. Estado de Mato Grosso do Sul. Brasília - DF: CPRM/DIEDIG/DEPAT, 2001. CD-ROM.

CREPANI, E.; MEDEIROS, J. S. de.; HERNANDEZ FILHO, P.; FLORENZANO, T. G.; DUARTE, V.; BARBOSA, C. C. F. Sensoriamento remoto e geoprocessamento aplicados ao Zoneamento Ecológico-Econômico e ao ordenamento territorial. São José dos Campos - SP: INPE, 2001.

EMBRAPA. Empresa Brasileira de Pesquisa Agropecuária. Zoneamento Agroecológico do Município de Anastácio-MS. Disponível em: https://goo.gl/gKXkhd. Acesso em 21dez.2012.

FELGUEIRAS, C. A. A tecnologia SPRING, breve histórico, status atual e evolução. In: SIMPÓSIO DE GEOTECNOLOGIAS NO PANTANAL. I, Campo Grande - MS, Anais... Campo Grande - MS: INPE, 2006, p. 811-824. Disponível em: http://goo.gl/MtbJ49. Acesso em: 15 ago. 2015 .

FERREIRA, E. M.; DRESCH, C. J.; AYACH, L. R. A modificação da paisagem no contexto histórico de ocupação do território do assentamento São Manoel - Anastácio-MS. Revista Geografar, Curitiba, v.11, n.1, 2016. p.5-25. Disponível em: https://goo.gl/o5Ys8h. Acesso em: 05 jun. 2018.

FERREIRA, M. B.; SALLES, A. O. T. Política ambiental brasileira: análise histórico institucionalista das principais abordagens estratégicas. Revista de Economia, Curitiba, v. 43, n. 2, p. 1-17, 2016. Disponível em: https://revistas.ufpr.br/economia/article/download/54001/33016. Acesso em: 05jun.2018.

GASS. S. L. B. VERDUM, R. Subsídios ao zoneamento ambiental do estado do Rio Grande do Sul, Brasil. Boletim Geográfico do Rio Grande do Sul, Porto Alegre, n. 28, p. 78-102, set. 2016. Disponível em: https://goo.gl/LSYqW9. Acesso em: 05jun.2018.

GUEDES, J. C. F.; MEDEIROS, A.D.; COSTA, D. F. S. Estratégia de Zoneamento Ambiental Aplicada a Caracterização Ambiental de Bacias Hidrográficas do Semiárido Brasileiro: Estudo de Caso na Microbacia do Rio Barra Nova - RN/PB. Revista Internacional de Direito Ambiental e Políticas Publicas, Macapá, v. 2, n. Especial, p. 1011-1024, 2016. Disponível em: https://goo.gl/187j4y. Acesso em 05jun.2018. 


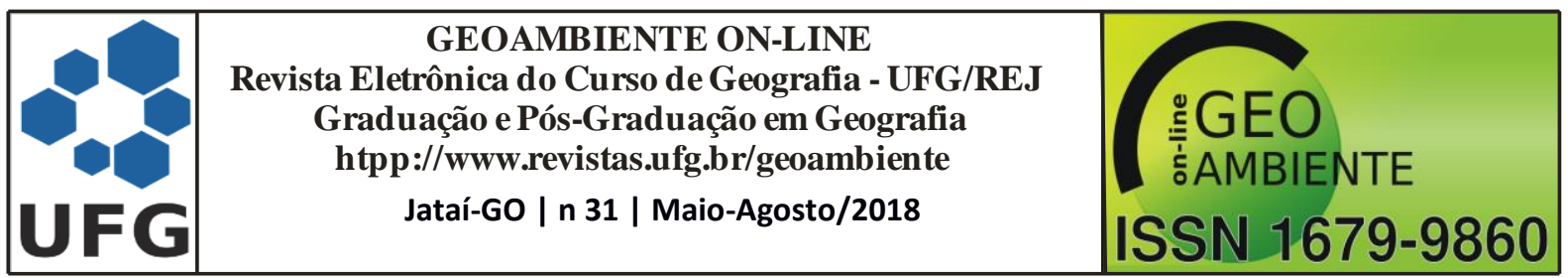

HENRIQUES, R. P. B. O futuro ameaçado do cerrado brasileiro. Ciência Hoje, [S.1], v.33, n.195, p.34-39, 2003. Disponível em: http://goo.gl/pDZJFp. Acesso em: 19fev.2016.

IBGE. Instituto Brasileiro de Geografia e Estatística. Manual técnico de uso da terra. 3. ed. Rio de Janeiro - RJ: IBGE, 2013.

IBGE. Instituto Brasileiro de Geografia e Estatística. Sinopse do Censo Demográfico 2010. Disponível em: https://goo.gl/1MR6BV. Acesso em 25set.2015.

LAGE, C. S.; PEIXOTO, H.; VIEIRA, C. M. B. Aspectos da vulnerabilidade ambiental na Bacia do Rio Corrente-BA. GeoTextos, Ondina. v.4, n.1, p.11-36, 2008. Disponível em: http://goo.gl/eddWpF. Acesso em: 19nov.2015.

LANZA, D. A.; POTT, A.; SILVA, J. dos S. V. da. Vegetação e uso da Terra na Unidade de Planejamento e Gerenciamento Rio Verde, Mato Grosso do Sul. Revista GeoPantanal, Corumbá, n. 16, p. 251-262, 2014. Disponível em: https://goo.gl/Z8bwGU. Acesso em: 05jun.2018.

LIMA, J. E. F. W. Situação e perspectivas sobre as águas do cerrado. Ciencia Cultural, São Paulo, v.63, n.3, p.27-29, 2011. Disponível em: https://goo.gl/HtRVNW. Acesso em: 08jun. 2018.

MAFRA, N. M. C. Erosão e Planificação de uso do solo. In: GUERRA, A. J. T.; SILVA, A. L. da. BOTELHO, R. G. M.; (Orgs.). Erosão e Conservação dos Solos: conceitos, temas e aplicações. 2. ed. Rio de Janeiro - RJ: Bertrand Brasil, p. 301- 322, 2005.

MATO GROSSO DO SUL. Atlas multirreferencial. Campo Grande - MS: SEPLANCT/MS, 1990. MOREIRA, M. A. Fundamentos do sensoriamento remoto e metodologias de aplicação. 4. ed. Viçosa, MG: UFV, 2012

RAMOS, A. M.; SANTOS, L. A. R. dos; FORTES, L. T. G. Normais climatológicas do Brasil, 1961-1990. Brasília-DF: Instituto Nacional de Meteorologia, 2009. Disponível em <http://goo.gl/uQgnWK> Acesso em: 25 out. 2010.

RIBEIRO, C. A. A. S.; SOARES, V. P.; OLIVEIRA, A. M. S.; GLERIANI, J. M. O desafio da delimitação de áreas de preservação permanente. Árvore, Viçosa, v.29, n.2, p.203-212, 2005. Disponível em: http://goo.gl/RYtY9t. Acesso em: 15fev.2016.

SANCHEZ, L. E. Avaliação de impacto ambiental: conceitos e métodos. 2. ed. São Paulo - SP: Oficina de Textos, 2013.

SANTOS, R. F. dos. Planejamento ambiental: teoria e prática. Oficina de textos, 2004. 


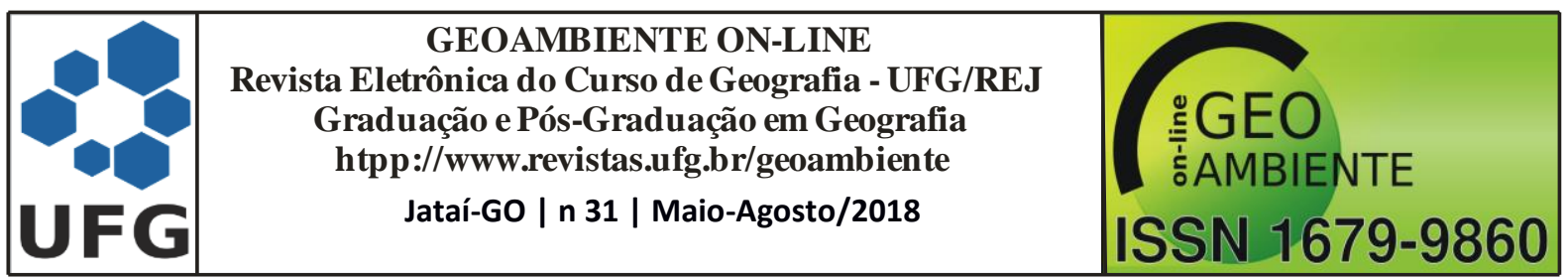

SÂO MIGUEL, A E. MEDEIROS, R. B. GOMES, W. M. Alterações no Uso e Cobertura da Terra no município de Inocência/MS, nos anos de 2000, 2008 e 2014. Fórum Ambiental da Alta Paulista, v.13, n.2, p. 20-30, 2017. Disponível em: https://goo.gl/m23nyB. Acesso em: 05 jun. 2018.

SAWYER, D. Fluxos de carbono na Amazônia e no Cerrado: um olhar socioecossistêmico. Sociedade e Estado, v. 24, n. 1, 2009. p. 149-171. Disponível em: https://goo.gl/nLw7Pd. Acesso em: 11jun.2018.

SEIFFERT, M. E. B. Gestão ambiental: instrumentos, esferas de ação e educação ambiental. 2. ed. São Paulo - SP: Atlas, 2011.

SILVA, A. M. da. Relações entre os processos erosivos e sedimentológicos de bacia hidrográfica em função das características físicas e de uso do solo estudadas através de técnicas de Geoprocessamento. 1999. 247fls. Tese (Doutorado em Ciências de Engenharia Ambiental) Escola de Engenharia Ambiental de São Carlos, São Carlos - SP.

SILVA, E. V.da. RODRIGUEZ, J. M. M. Planejamento e zoneamento de bacias hidrográficas: a geoecologia das paisagens como subsídio para uma gestão integrada. Caderno Prudentino de Geografia, Presidente Prudente, n.36, Volume Especial, p. 4-17, 2014. Disponível em: http://revista.fct.unesp.br/index.php/cpg/article/view/3170/2654. Acesso em: 05jun.2018.

SILVA, J. S. V. dos; SANTOS, R. F. dos. Estratégia metodológica para o zoneamento ambiental: A experiência aplicada na Bacia Hidrográfica do Alto Rio Taquari. Campinas, SP: Embrapa Informática Agropecuária, 2011.

TEIXEIRA, N. F. F.; SILVA, E.V. da.; FARIAS, J. F. Geoecologia das paisagens e planejamento ambiental: discussão teórica e metodológica para a análise ambiental. Revista Internacional de Direito Ambiental e Políticas Públicas, Macapá, n. 9, p. 147-158, 2017. Disponível em: https://goo.gl/NS1J6W. Acesso em: 05ago.2018.

USGS. United States Geological Survey. Earth Explorer. Disponível em: http://earthexplorer.usgs.gov/. Acesso em: 15ago.2015.

VALERIANO, M. de M. TOPODATA: guia de utilização de dados geomorfométricos locais - São José dos Campos: INPE, 2008. 